\title{
THE SOCIOMATERIALITY OF INFORMATION SYSTEMS: CURRENT STATUS, FUTURE DiRECTIONS
}

\author{
Dubravka Cecez-Kecmanovic \\ Australian School of Business, University of New South Wales, Sydney, NSW 2052, AUSTRALIA \{dubravka@unsw.edu.au\} \\ Robert D. Galliers \\ Bentley University, Waltham, MA 02452 U.S.A. \{rgalliers@bentley.edu\} \\ Ola Henfridsson \\ Warwick Business School, The University of Warwick, Coventry CV4 7AL UNITED KINGDOM \{ola.henfridsson@wbs.ac.uk\} \\ Sue Newell \\ Bentley University, Waltham, MA 02452 U.S.A. \{snewell@bentley.edu\} \\ and Warwick Business School, The University of Warwick, Coventry CV4 7AL UNITED KINGDOM \\ Richard Vidgen \\ Hull University Business School, Hull HU6 7RX UNITED KINGDOM \{r.vidgen@hull.ac.uk\}
}

\section{Introduction}

Our motivation for putting together this special issue on "Sociomateriality of Information Systems and Organizing" was the mounting interest in the relationship between the social and the material, in the context of our increasingly digital society. ${ }^{1}$ The attention to this relationship is manifested in the emergence of studies of technology intended to augment and complement, but also and importantly, to question the received views on technology in social life (see Carlile et al. 2013a; Leonardi et al. 2012; Suchman, 2007).

Sociomateriality stands out as a symbol for the interest in the social and the technical, and in particular, the subtleties of their contingent intertwining. Promoted in the IS discipline primarily by Wanda Orlikowski and Susan Scott (Orlikowski

\footnotetext{
${ }^{1}$ In addition, this special issue was motivated by a joint Australian School of Business-Bentley University working conference, "On Sociality, Materiality and Sociomateriality of Information Systems and Organizations," that was held at the University of New South Wales, Sydney, Australia, on March 12-13, 2010.
}

2007, 2010; Orlikowski and Scott 2008), this "umbrella" concept, to use their terminology, has fostered an entire stream of new research based on a so-called relational ontology (e.g., Slife 2004; Wagner et al. 2011, Wagner et al. 2010). The assumptions underpinning a relational ontology are different from those underpinning the substantialist ontology that dominates IS and management research (Carlile et al. 2013b; Emirbayer 1997; Introna 2013). While a substantialist ontology assumes that human beings and things - the social and the material - exist as separate and self-contained entities that interact and affect each other, a relational ontology assumes that "the social and the material are inherently inseparable" (Orlikowski and Scott 2008, p. 456). Entities, human beings, and things exist only in relations: they are performed and continuously brought into being through relations (Latour 2005; Orlikowski 2010). This relational underpinning of sociomateriality has many implications for extant notions of technology, agency, society, materiality, morality, and ethics, to name just a few (Carlile et al. 2013b).

The relational basis of the original proposal for a sociomaterial perspective in our discipline (Orlikowski 2007, 2010; 
Orlikowski and Scott 2008) has triggered counterviews and competing proposals, leading to multiple uses of the term (Kautz and Jensen 2013). Faulkner and Runde (2012), for instance, specifically dispute the relational basis of sociomateriality, arguing that its key determination is the focus on material agency in explaining the social, for which they prefer a substantialist ontology. They agree that "technological objects are shaped by the activities of humans, [and] that technological objects in turn shape human activities" (p. 64), but assume their separate existence. Similarly, Leonardi (2012, pp. 34, 42) uses the notion of sociomateriality to emphasize the role of materiality in all phenomena that we typically consider social. He considers the materiality of technology as independent of people, persisting across space and time, while presenting specific affordances and constraints for people using technology within sociotechnical systems. Yet another strand of thinking is represented by Mutch (2013), who views the relational basis for sociomateriality (Barad 2007; Orlikowski 2007, 2010) as a "wrong turning," suggesting critical realism as a more appropriate foundation to study materiality and its role in organizing. ${ }^{2}$

The sometimes confusing, controversial and confrontational (Kautz and Jensen 2013; Scott and Orlikowski 2013) debate on sociomateriality of information systems and organizing comes as no surprise. In fact, we view it as quite healthy for an emerging stream of research. More surprising perhaps are the quite charged responses to the initial, relational proposal for a sociomaterial perspective. At times, the debate smacks of exclusionary arbitrage, with critics apparently seeking to distinguish right from wrong and to determine what deserves to be pursued in future research, and what does not. On the other hand, there are others who appear to be more flexible, recognizing that sociomaterial accounts in IS and organizing adopt different ontological positions (see Jones 2014), leading to diversity in sociomaterial scholarship. We view this as a positive development that demonstrates the willingness of IS researchers to identify different and alternative ways of understanding the relationships between the social and the technical.

In this spirit, this special issue advocates a position that no perspective or paradigm guarantees privileged access to truth. Our intention is not to adjudicate among different perspectives on sociomateriality or to seek their convergence. Instead, we offer a forum for well-argued views on the topic from different standpoints. Thus, our intention is not to bring the debate to a close but to stimulate further interest in the topic. In this spirit, we open this special issue with a brief

\footnotetext{
${ }^{2}$ See the introduction by Mingers et al. (2013) to the special issue of MIS Quarterly on the subject of critical realism in IS research.
}

account of the philosophical battleground of sociomateriality. To provide a historical context, we also explore the roots of the notion of sociomateriality. We then review the research methods adopted by researchers in recent papers inspired by sociomateriality and question the extent to which they reflect the distinct nature of sociomaterial entanglements. Summaries of the articles published in this special issue are provided together with implications and suggestions for future research.

\section{Introducing the Battleground... and the Road to Peace?}

Since its infancy, IS research has struggled to reconcile the simultaneous technological and social nature of information systems. Reporting on ideas originally developed more than 60 years ago, Trist (1981, pp. 12-13) noted that

if the material and symbolic cultures of a society were not connected by any simple principle of linear causality...they were nevertheless intertwined in a complex web of mutual causality....In the language of E. A. Singer (1959) they were co-producers of each other.

This represented a significant milestone in recognizing the interrelationships between the social and the technical, but it was still based on an assumption of duality between the technological and the social, an assumption that continues to be reflected in both technology-focused (e.g., Benbasat and Zmud 2003) and social perspectives on IS (e.g., Mingers and Willcocks 2004). This duality presents a conceptual difficulty when faced with the increasingly complex materiality of everyday IS-mediated work practices (Leonardi and Barley 2008; Orlikowski 2007), in which the technological and the social are inextricably entangled in multiple ways. It is this entanglement and the mutual intertwining of technology and social life in everyday practices that motivated the questioning of the relationship between, and the assumed duality of, the material/technical and the human/social (Orlikowski and Scott 2008; Slife 2004; Woolgar 2002). It is, therefore, not surprising that different conceptualizations of sociomateriality emerged, taking different positions on this duality and allowing for different theorizing of the nature of IS and organizing.

The notion of sociomateriality proposed by Orlikowski (2007, 2010) and Orlikowski and Scott (2008) is founded on the agential realist philosophy developed by Barad (1998, 2003, 2007). This conception of sociomateriality 
makes a distinctive move away from seeing actors and objects as primarily self-contained entities that influence each other... away from discrete entities of people and technology...to composite and shifting assemblages (Orlikowski and Scott 2008, p. 455).

Instead of assuming that entities, people, and technologies have given, inherently determinate boundaries and properties, they are seen as relational effects, continuously performed in a web of relations. It is important to note that relationality here is ontological:

Relationships are not just the interactions of what was originally nonrelational; relationships are relational "all the way down." Things are not first selfcontained entities and then interactive. Each thing, including each person, is first and always a nexus of relations... all things, including all practices, have a shared being and a mutual constitution in this sense. They start out and forever remain in relationship (Slife 2004, p. 159).

The view of sociomateriality founded on such an ontological position-which Slife (2004) refers to as "strong relationality" - implies that reality is not given but performed through relations in practice. This represents an important shift from understanding people and technologies, each characterized by specific essential properties and boundaries that interact and mutually impact each other in practice, toward understanding the performative nature of practices and the ways in which people and technologies, their properties and boundaries, are enacted and reenacted in practice.

Performativity of practice is further elaborated by the notion of agential intra-action introduced by Barad (2003). It is through intra-action that material-discursive practices reconfigure relations and thus delineate entities and enact their particular properties. When such intra-activity produces local determinations and makes specific identities of human or social actors, of objects and technologies, they become enacted as such and can then be perceived as having given boundaries and properties. In Barad's vocabulary it is the agential cut performed by practice that makes all entities what they are in a particular situation. While people and technologies are never fixed - as they are differentially enacted and reenacted in practice through iterative intra-action - they may be stabilized for specific purposes by agential cuts.

This view of performativity is posthumanist as it does not privilege human actors, that is, it does not take the distinction between humans and technologies (or nonhumans generally) as given. Posthumanist performativity instead recognizes composite assemblages of humans and technologies as ontologically inseparable components. These heterogeneous components do not precede their interaction but rather emerge through intra-acting. This assumption allows Barad (2003) to reformulate the notion of agency and in particular to transcend the duality of human versus technological agency. Instead of locating agency in humans (emphasizing intentionality and subjectivity), or in technologies (as more or less autonomous), Barad conceives of agency as the "enactment of iterative changes to particular practices through the dynamics of intraactivity" (2003, p. 827). Intra-action can thus be understood as the "mutual constitution of entangled agencies" (Barad 2007 , p. 33). Such a broad view of agency draws attention to the possibilities and accountability of intra-acting for performing particular realities.

The performative idiom can be traced back to Pickering $(1993,1995)$ who adopts a posthumanist view by decentering the human subject through acknowledging a role for nonhumans, or material, in scientific practices. The performative idiom, says Pickering, "subverts the black-and-white distinctions of humanism/antihumanism and moves into a posthumanist space, a space in which the human actors are still there but now inextricably entangled with the nonhuman, no longer at the center of the action and calling the shots" (1995, p. 26). Inspired by actor network theory (ANT), Pickering (1993) acknowledges that both humans and nonhumans have agency and argues that they are "mutually and emergently productive of one another" (p. 567). However, he does not accept that they are symmetrical (as is assumed by ANT), claiming that human agency has intentionality while nonhuman agency does not. ${ }^{3}$ For this reason Pickering's posthumanist view of performativity and agency is seen as ambivalent (Barad 2007). This notwithstanding, Pickering's concept of the mangle of practice offers an innovative way to explore trajectories of human and material agency in practice and in the manner in which they are emergently transformed and "constitutively enmeshed by means of a dialectic of resistance and accommodation" (1993, p. 567). The mangle of practice is adopted and extended by Venters et al. (2014) when they examine digital infrastructure emergence as an "unstable and evolving sociomaterial configuration" (p. 931).

In view of the ideas of posthumanist performativity and agency, Barad calls into question a Newtonian conception of matter as a fixed substance with inherent properties:

\section{Matter is substance in its iterative intra-active becoming — not a thing, but a doing, a congealing of}

\footnotetext{
${ }^{3}$ This is echoed by Suchman (2007) who argues that "persons and artifacts do not constitute each other in the same way" (p. 269).
} 
agency. Matter is a stabilizing and destabilizing process of iterative intra-activity. Phenomena come to matter through this process of ongoing intraactivity. That is, matter refers to the materiality and materialization of phenomena, not to an assumed, inherent, fixed property of abstract, independently existing objects (2007, p. 210).

Matter is not a given or fixed substance, or just a product of human agency, but is iteratively performed through intraactions. Of particular interest in IS is the materiality of technology, understood as a process of materialization enfolding in material-discursive practices of IS development, implementation, and use. Materiality of technology is not given in the nature of technology or an effect of human agency. Materiality of technology is iteratively performed by intra-acting and is thus enacted as particular material-discursive configurations of phenomena. Strictly speaking, it is not materiality of technology we are talking about but materiality of composite assemblages of technology, people, work, and organizing in ongoing intra-action. Materiality is not an arbitrary construction, though, as intra-activity implies the doing of all involved and the congealing of agency in the enfolding nexus of relations.

In an empirical study of petroleum production, Østerlie et al. (2012) explore and theorize further the performative notion of materiality. They define material reality as

the stuff the world is made up of [that includes] both the physical phenomena to be monitored, and the material sensors and other computing equipment used to generate data about the phenomena (p. 86).

Through a study of practices of monitoring and controlling petroleum production and the use of sensors connected to computers to generate and visualize data about the mass streaming out of the wells, Østerlie et al. build on and extend the performative view of materiality:

The material arrangements of sensors and other computing equipment that generate and visualize real-time data... [about well flows] reside along the boundary between the undifferentiated well flow and a world of semantics that says something about this well flow. Dual materiality distinguishes between these two modes of materiality: the material phenomena that the engineers are trying to grasp versus the materiality of the tools from which they approach it....digital technology becomes important because its materiality plays an integral part in creating, not simply representing, the materiality of physical phenomena (p. 86).
By focusing on practices, Østerlie et al. foreground the intersection between the undifferentiated phenomena of well flows and the information system, reflecting differentiations made by humans and their tools (sensors and other equipment), and thus explaining their ongoing mutual materialization. While material phenomena of the well flow (e.g., liquids, gases, sand) admittedly exist, they are undifferentiated until the sensors mounted along the pipelines send signals that, through a series of transformations, assign specific properties to these material phenomena. These properties are not inherent in the well flow; nor are they abstract concepts: they emerge through dual materialization of the phenomena observed and the arrangements of sensors, computer equipment, and algorithms as part of practice.

The stream of research, then, that emerges following the original perspective on sociomateriality is primarily demarcated by relational ontology, posthumanist performativity, and a nonessentialist view of materiality (Orlikowski 2007, 2009; Orlikowski and Scott 2008). It has been debated, adopted and developed further through empirical studies (e.g., CecezKecmanovic et al. 2014; Jones 2013; Orlikowski and Scott 2013; Østerlie et al. 2012; Scott and Orlikowski 2012; Shotter 2013). While this stream adopts agential realism as an exemplar foundation, offering a particular ontological and epistemological position and vocabulary (Barad 2003, 2007), there are others equally bold and innovative. For instance, Introna $(2011,2013)$ takes a different route to overcome the bifurcated ontology of being or human centered metaphysics, and develops a sociomaterial foundation based on Heidegger, following Harman's (2002) interpretation. Similarly, Riemer and Johnson (2012) develop a sociomaterial account of technology (specifically, social media) appropriation in organizations by drawing from Heidegger's analysis of equipment.

Moreover, the original conception of sociomateriality has been questioned, as we indicated above, and alternative views on sociomateriality have been proposed. Leonardi (2012, 2013 ) is the most vocal in arguing for a view of sociomateriality that is grounded in substantialist ontology. $\mathrm{He}$ recognizes that

materiality is present in each and every phenomenon that [organization scholars] consider "social".... talking about sociomateriality is to recognize and always keep present to mind that materiality acts as a constitutive element of the social world and vice versa (p. 34).

He also talks of sociomaterial practice as the "space in which the social and the material become constitutively entangled" (p. 35). While these claims may suggest some similarity with the original sociomaterial proposal, Leonardi is critical of this 
proposal and its ontological grounding and offers a significantly different conception of sociomateriality based on substantivist assumptions.

The substantialist ontology "takes as its point of departure the notion that it is substances of various kinds (things, beings, essences)...[as] self-subsistent entities, which come 'preformed" and then involve themselves in dynamic relations (Emirbayer 1997, pp. 282-283). Relations among the selfcontained entities are information exchanges, which affect only their nonessential properties; that is, they do not change what they actually are. These relations or interactions, Slife (2004) suggests, can be seen as a "weak form of relationality because members of the interaction 'act on' each other from the outside" (p. 158).

Leonardi (2011) explores the interweaving of human and material agencies. While being essentially different, human and material agencies are effective in producing outcomes only when they are mutually interlocking. Following Sassen (2006), Leonardi uses the notion of imbrication, which assumes the inherent distinction between human and material agencies while simultaneously denoting their synergistic interaction:

By keeping the distinction between human and material agencies, the imbrication metaphor asserts a slightly different relationship: people have agency and technologies have agency, but ultimately, people decide how they will respond to a technology (p. 151).

Leonardi (2013, p. 144) defines materiality as "the arrangement of a technological artifact's physical and/or digital materials into particular forms that endure across differences in place and time and are important to users" and proposes that it makes "good empirical sense to treat a technological artifact's materiality as something that exists at least physically (if not conceptually) apart from the people who create and use it." Materiality is intrinsic to technology, independent of its use and the context in which technology is used. In other words, Leonardi (2012, p. 29) is suggesting that materiality "identifies those constitutive features of a technology" or the inherent properties of technology that do not change across locations and time. Once technology is built its materiality is fixed, unless some subsequent redesign is undertaken. When implemented in an organizational context, technology's materiality "becomes important because users react to the technology's materiality - a materiality they perceived as bounded and stable - when translating it from the realm of the artifactual into the realm of the social" (Leonardi 2013, p. 162).
The assumption that technology and other objects have inherent properties, as do human actors, is widely accepted and in large part taken for granted in the IS and organization studies literatures. ${ }^{4}$ In this sense, Leonardi (2012, pp. 42-43) does not betray the traditional realist position when he argues that the social and the material are different realms - that social agency ("coordinated human intentionality") and material agency ("ways in which a technology's materiality act," provoked or instructed by humans) are different in nature. While social and material agencies are fundamentally different with respect to intention, they impact, mutually shape, or mediate each other and become imbricated in social practice (Leonardi 2011).

As this brief discussion shows, there exist various ways of thinking that coexist under the umbrella of sociomateriality. Thus, this variety is manifested in different conceptions of the duality of, and the ontological separation between, the social and the technological; the subject and the object; the world of persons and the world of things. ${ }^{5}$ Each conception provides particular insights into the manner in which these are entangled, imbricated, mutually shaping, or co-constituting. Yet, each challenges conventional modernist distinctions between idealism and materialism, and subjectivism and objectivism (Law 2004; Leonardi and Barley 2010). The questions raised by all of these sociomaterial accounts broadly address those previously surfaced in the IS discipline, including the early formative ideas of the sociotechnical school (for a review, see Mumford 2006) and in the debate about the role of the IT artifact in IS research (King and Lyytinen 2006; Orlikowski and Iacono 2001). We turn to these intellectual roots next.

\section{The Roots of Sociomaterial Thinking}

Sociomaterial thinking has numerous intellectual roots that have not been clearly identified nor acknowledged. Indeed, it would seem that many students of sociomateriality are puzzled by its perceived similarity with some established streams of thought (see Leonardi 2012). It would, thus, appear useful to recall the historical roots of sociomateriality in traditions such as ethnomethodology; science and technology studies, post-structuralism, post-modernism, and feminist technoscience studies. However, since the socio-

\footnotetext{
${ }^{4}$ It is worth noting that the substantivist thinking is embedded in Western languages (Elias 1978) and is taken as common sense.

${ }^{5}$ See the paper by Jones (2014), which differentiates between strong and weak sociomateriality.
} 
technical systems perspective (e.g., Mumford 2006; Trist and Bamforth 1951), ANT (e.g., Callon 1986a, 1986b; Latour 2005; Law 2004), and practice theory (e.g., Bourdieu 1977; Rezkwitz 2002; Schatzki 1996) stand out as predecessors and contributors to the articulation and development of the different conceptualizations of sociomateriality in the IS discipline, we consider these in more detail below. In doing this, we intend to demonstrate that each of these predecessors contributes to the umbrella that constitutes sociomaterial scholarship, allowing researchers to select conceptual (and methodological) tools that fit the purpose of their particular research agenda.

\section{Sociotechnical Systems}

The sociotechnical systems approach is important both as a precursor to sociomaterial thinking and also as a foundation for a particular view on sociomateriality. Sociotechnical systems, as an approach and as a new field of inquiry, emerged in the middle of the last century (e.g., Trist and Bamforth 1951). Trist and his fellow researchers from the Tavistock Institute of Human Relations ${ }^{6}$ developed sociotechnical thinking to counter tendencies "to subjugate man to the machine" and to emphasize the interrelatedness of technological and social systems (Bjørn-Andersen et al. 1982, p. xiv). The core concern was to find the best match between, and jointly optimize, the technological and social components in designing sociotechnical systems. This was assumed to lead to both improved economic performance and quality of working life (Trist 1981).

Sociotechnical systems thinking flourished in a variety of disciplines, including IS and organization studies. The work of Enid Mumford (see Avison et al. 2006), an affiliate of the Tavistock Institute, was particularly influential in advancing principles for designing information systems that improve the general conditions of work (quality of work life and job satisfaction) while at the same time increasing workplace performance: "making the best use of people, and the best use of technology" (Mumford 1983, p. 10; see also Mumford 2003, 2006). More broadly, the contribution of the sociotechnical systems approach is important as it explicitly addressed the complex issues of intertwining the technical aspects of IS and human and social aspects of work organizations. Although the joint optimization of technical and social aspects was the hallmark of the sociotechnical systems approach, it tended at times to privilege the technical, or at

\footnotetext{
${ }^{6}$ For a history of the Tavistock Institute, go to http://www.tavinstitute.org/ who-we-are/our-history/.
}

other times the social (see Leonardi 2012; Orlikowski 2010). However, as Robey et al. (2013) argue, privileging either is not inherent in the sociotechnical systems approach that remains capable of including the technical/material as well as the social/human in explaining organizational stability and change. Importantly, while doing so, the sociotechnical systems approach preserves the ontological distinctions between the social and the material, a position reinforced by more recent studies of IS and organizing that "demonstrate the viability of a socio-technical approach in which the ontological distinction between social and technical reality is maintained" (Robey et al. 2013, p. 385; see also Leonardi 2011, 2012).

The sociotechnical systems approach can thus be seen as a historically relevant intellectual tradition for the development of the sociomaterial approach in at least two ways. By drawing attention to, and encouraging deeper insights into, the intertwining and interpenetration among technological and human processes, the sociotechnical systems approach paved the way for sociomaterial thinking. While Leonardi's approach to sociomateriality, being grounded in substantivism, is a reinterpretation and continuation of the sociotechnical tradition, the relational view of sociomateriality (Orlikowski and Scott 2008) represents a break and discontinuity. This discontinuity is also characteristic of ANT.

\section{Actor Network Theory}

ANT, which originated within science and technology studies (Callon 1986a, 1986b, 1999; Hanseth and Monteiro 1997; Latour 2005; Law 2004, 2008a, 2008b; Mitev and Howcroft 2011; Mol 1999, 2002), is another important intellectual tradition in the development of sociomaterial thinking. A distinguishing feature of ANT is the inclusion of nonhumans as actors in attempts to understand the social (Latour 2005). Humans and nonhumans are called actants in ANT language. In this regard, ANT decenters the human subject and considers heterogeneous actors-people, natural phenomena, technologies, documents, knowledge, social structures - as being equally engaged in and responsible for reassembling the social. ANT focuses on the relations that constitute actor networks and perform and temporally stabilize social arrangements; social arrangements are thus relational effects rather than entities with predefined qualities (Law 2008a). A network of interest, as Callon (1999) explains, is

not a network of connecting entities which are already there, but a network that configures ontologies. The agents, their dimensions, and what they are and do, all depend on the morphology of the relations in which they are involved (pp. 185-6). 
The world is thus seen as complex, temporally emerging, and continuously reconfiguring actor networks.

ANT views relationality as ontological: actants are enacted and brought into being through relations, and have no existence outside actor networks. In turn, this implies that human actors or technologies "are not given and do not exist in and of themselves" (Law 2004, p. 161), but are continuously enacted relational effects. ANT is thus concerned with how relations are performed and how actors get enacted, however temporally. In Law's words,

Instead of asking why things happen it asks how they occur. How they arrange themselves. How the materials of the world (social, technical, documentary, natural, human, animal) get themselves done in particular locations for a moment in all their heterogeneity. And how they go on shifting and relating themselves in the processes that enact realities, knowledges and all the rest" (2008a, p. 632).

It is fair to say that ANT, and science and technology studies in general, have influenced the development of sociomaterial thinking. They offered an early take on relational ontology, nonessentialism and post-humanism. In line with ANT, the relational view of sociomateriality (e.g., Orlikowski and Scott 2008) views heterogeneous actors as relational effects. Like ANT, it does not privilege minds over materials and does not limit agency to humans. However, it is important to acknowledge that sociomateriality is proposed as a more abstract material-semiotic approach that does not necessarily imply any particular theory or methodology. ANT's rich tradition, its vocabulary, theoretical and methodological developments, provide important resources for sociomaterial inquiry but are by no means mandatory or even implicated by the approach. While some sociomaterial studies have adopted a particular ANT methodology (e.g., Cecez-Kecmanovic et al. 2014), others have applied a variety of different methodologies (e.g., Huang et al. 2014; Introna 2011; Wagner et al. 2011).

\section{Practice Theory}

A third intellectual tradition of relevance for sociomateriality is practice theory, and the ideas originating in the "practice turn" in the social sciences, and specifically in organization studies (Feldman and Orlikowski 2011; Gherardi 2012; Nicolini 2013; Rouse 2007; Schatzki 1996, 2002; Whittington 2006). ${ }^{7}$ Practice theory is concerned with practice as the

\footnotetext{
${ }^{7}$ For a recent consideration of practice theory as it relates to IS strategizing, see Peppard et al. (2014); for a call for a joint research agenda, see Whittington (2014).
}

principal constituent of social affairs, and thus a basic epistemic object of social theory. As Nicolini writes,

practice is central to understanding human conduct because practices constitute horizons of intelligibility, and allow us to respond to different matters in different ways. In so doing, practices constitute conditions of life and worlds (2013, p.164).

Practices are thus central to any account of social phenomena relevant to social sciences, information systems, and organization studies.

Schatzki's practice theory $(2002,2005)$ is humanist, or more precisely agential humanist, as for him practices are social: it is humans who carry out practices and set in motion processes of intelligibility. While human actions involve and can be affected by artifacts and material arrangements, they need to be differentiated as only human action can attribute purposefulness and affectivity. Material arrangements are important in terms of spaces and configurations of objects within spaces, such as the hospital or office, where practices enfold, and various technological artifacts make possible and/or constrain actions. Performativity of different material arrangements thus plays an important role as they (material arrangements) are intertwined with practices and "house" them.

More recent work in practice theory has been influenced by science and technology studies, most prominently ANT (Feldman and Orlikowski 2011; Gherardi 2012). A posthumanist practice theory takes more seriously the consequential role of objects, artifacts, and material arrangements in the production of social phenomena. Social practices consist of heterogeneous relations between humans and nonhumans, with neither being privileged over the other. Together with humans, things and materials are active elements of practice, with agency distributed relationally between them, "performed through networks of connectionsin-action, as life-world and dwelling" (Gherardi 2012, p. 77). Gherardi talks of an ecological model of practice, inspired by ANT studies, that does not give ontological priority to either humans or nonhumans (the social or the technological), and conceives of practice as the intermeshing of the discursive and the material that is mutually constitutive and continuously becoming, thus emphasizing the dynamic, ambiguous, and precarious nature of practice.

This branch of practice theory is skeptical toward, and rejects, the taken-for-granted dualities between mind and body; objective and subjective; social and material; cognition and action; structure and agency; free will and determination (Rezkwitz 2002). Practice theory, as Feldman and Orlikowski 
(2011, p. 1242) point out, "enables scholars to theorize the dynamic constitution of dualities and thus avoid the twin fallacies of 'objectivist reification' on the one hand and 'subjectivist reduction' on the other."

As this brief discussion shows, practice theory denotes a family of theories that provide not only important resources for understanding social life and organizing; it also resonates with other developments that have influenced sociomaterial thinking. Practice theory has been a source of inspiration for practice-based studies in information systems and organizational studies, and has more recently promoted practice as epistemology (Gherardi 2012). The new term sociomaterial practices has been debated by drawing from different streams of practice theory. Orlikowski (2007) and Gherardi (2012) refer to sociomaterial practices when discussing the constitutive entanglement of technology and everyday practices. When embedded and embodied in situated practice, technology's performativity is sociomaterial. On the other hand, Leonardi (2012) uses sociomaterial practice to denote a space where human actors and material artifacts interact and their (distinct) agencies imbricate, which is in accord with the humanist vein of practice theory.

\section{Research Methods and Sociomateriality}

Thus far, we have considered the roots of, and debates concerning, sociomateriality. We now turn our attention to research methods in order to more closely examine current methodological practices in sociomateriality research. It would be natural to expect that theoretical developments would be followed by methodological advancements aimed at helping researchers release the potential of sociomaterial thinking still further. While there have indeed been proposals to address the implications of sociomateriality for methodology_for example, Bruni (2005) addresses the "ethnography of objects"-overall, our review of existing literature (see below) suggests that methodological advances have failed to keep pace with theoretical developments.

To get a sense of current methods used in sociomaterial research, we selected from Jones's (2014) review of papers that were published in 2013 those papers that include empirical material. This selection resulted in 14 papers, which are analyzed in Table 1, showing their theoretical grounding and the research method adopted (i.e., the approach taken to data collection and data analysis). Most of the papers take a relational view of sociomateriality, typically drawing on Orlikowski (2007) and Orlikowski and Scott (2008), but in two cases delve more deeply by considering Barad's (2007) work. As for research method, (1) one paper (Liang et al.) has a passing mention of sociomateriality in what is otherwise a traditional quantitative piece of research, and (2) three papers (Ferguson et al.; Hauptman and Steger; Mazmanian et al.) invoke sociomateriality in the second half of the paper, typically in the discussion section and as a call for future work. For these papers, we do not include details of the research method since the authors have not adopted a sociomaterial framing for their actual data collection, hence they are marked as " $\mathrm{n} / \mathrm{a}$ " in the research method column.

The remaining 10 papers use sociomaterial ideas and theory to form a framework for investigation, with varying degrees of depth: (3) two papers (Bansal and Knox-Hayes; Boos et al.) use sociomateriality as a lens to frame a discussion of case study data; (4) six of the papers take a human-centered, interpretive case study approach using ethnographic methods (Jarrahi and Sawyer; Oborn et al.; Panourgias et al.; Porter; Pritchard and Symon; Slade); (5) while still being predominantly human-centered, two papers (De Vaujany et al.; Stein et al.) start to bring technology to the foreground. For the papers in the fourth and fifth categories, data analysis typically involves coding to identify themes and constructs (e.g., following Miles and Huberman 1994), and in two cases, narrative analysis (e.g., Phillips and Oswick 2012) as story telling (Pritchard and Symon; Stein et al.). Some use multiple sources of data, for example, interviews, observation, video recording of technology use, and analysis of sources such as blogs and emails. In one article, a survey with quantitative analysis is used to supplement the qualitative work (De Vaujany et al.).

\section{Critique of the Current Situation}

Our review of the methods used in the most recent literature (including the papers in this special issue) indicates that, despite the focus on exploring relationships between the social and the material, the social almost always seems to take precedence, with the material merely affording some social/ human intention. Thus, while all of these papers do tend to look at technology (i.e., its materiality) closely - thus taking material (or better, sociomaterial) agency more seriously than in much of the previous IS literature - the technologies, nevertheless, are often fairly mute, typically only represented by human spokespersons. This may be because, as Table 1 indicates, authors have tended to use much the same methods as we have used for examining IS phenomena from an interpretivist (but not relational) perspective (see Walsham 1993). Thus, we see heavy reliance on single cases, with interviews as the main source of data (albeit there tends to be more use of observation than in other qualitative studies), and one study (Stein et al.) does use some video recording in order to attempt 


\begin{tabular}{|c|c|c|c|c|}
\hline & $\begin{array}{l}\text { Research } \\
\text { Setting }\end{array}$ & $\begin{array}{l}\text { Theoretical } \\
\text { Grounding }\end{array}$ & Use of Sociomateriality & Research Method \\
\hline \multicolumn{5}{|c|}{ (1) Nominal Sociomaterial Accounts } \\
\hline Liang et al. (2013) & IT compliance & $\begin{array}{l}\text { Orlikowski and } \\
\text { Scott (2008) }\end{array}$ & $\begin{array}{l}\text { Quantitative study used with hypothesis } \\
\text { testing. SM is used to argue for fusing } \\
\text { of ERP technology and accounting } \\
\text { practice, but there are no implications } \\
\text { for the research model and SM is not } \\
\text { addressed in the discussion or in } \\
\text { recommendations for future research. }\end{array}$ & $\mathrm{n} / \mathrm{a}$ \\
\hline \multicolumn{5}{|c|}{ (2) Post Hoc Sociomaterial Accounts } \\
\hline $\begin{array}{l}\text { Ferguson et al. } \\
(2013)\end{array}$ & $\begin{array}{l}\text { Blogging and } \\
\text { development } \\
\text { professionals }\end{array}$ & $\begin{array}{l}\text { Orlikowski and } \\
\text { Scott }(2008)\end{array}$ & $\begin{array}{l}\text { Qualitative case study with interviews. } \\
\text { Sociomateriality is introduced in the } \\
\text { discussion and as a direction for future } \\
\text { work. }\end{array}$ & $\mathrm{n} / \mathrm{a}$ \\
\hline $\begin{array}{l}\text { Hauptmann and } \\
\text { Steger (2013) }\end{array}$ & $\begin{array}{l}\text { Social media and } \\
\text { human resource } \\
\text { management }\end{array}$ & $\begin{array}{l}\text { Orlikowski (2007); } \\
\text { Orlikowski and } \\
\text { Scott (2008) }\end{array}$ & $\begin{array}{l}\text { Case studies involving interviews and } \\
\text { analysis of blogging records. Social } \\
\text { and technical factors are analyzed } \\
\text { separately and SM is introduced into } \\
\text { the discussion to argue that the social } \\
\text { and technical structures are intertwined. }\end{array}$ & $\mathrm{n} / \mathrm{a}$ \\
\hline $\begin{array}{l}\text { Mazmanian et al. } \\
\text { (2013) }\end{array}$ & $\begin{array}{l}\text { Mobile devices } \\
\text { and knowledge } \\
\text { workers }\end{array}$ & $\begin{array}{l}\text { Leonardi and } \\
\text { Barley (2010); } \\
\text { Orlikowski and } \\
\text { Scott (2008). }\end{array}$ & $\begin{array}{l}\text { SM is introduced in the implications } \\
\text { section to highlight the importance of } \\
\text { materiality and to argue for its } \\
\text { importance in future work. }\end{array}$ & $\mathrm{n} / \mathrm{a}$ \\
\hline \multicolumn{5}{|c|}{ (3) Sociomaterial Plus (other non-sociomaterial lenses also applied) } \\
\hline $\begin{array}{l}\text { Bansal and Knox- } \\
\text { Hayes (2013) }\end{array}$ & $\begin{array}{l}\text { The natural } \\
\text { environment and } \\
\text { carbon markets }\end{array}$ & Orlikowski (2007) & $\begin{array}{l}\text { Uses SM to emphasize the role of } \\
\text { physical materiality for discursive } \\
\text { development of sociomaterial thinking. }\end{array}$ & $\begin{array}{l}\text { Data: descriptive case } \\
\text { study drawing on carbon } \\
\text { markets and a wind farm } \\
\text { Analysis: discursive, } \\
\text { arguing for a difference } \\
\text { between physical } \\
\text { materiality and socio- } \\
\text { materiality }\end{array}$ \\
\hline Boos et al. (2013) & $\begin{array}{l}\text { Internet of things } \\
\text { and the } \\
\text { pharmaceutical } \\
\text { industry }\end{array}$ & Orlikowski (2007) & $\begin{array}{l}\text { SM is used to frame a study of the } \\
\text { Internet of things and their relationship } \\
\text { to accountability and control. }\end{array}$ & $\begin{array}{l}\text { Data: vignettes (descri- } \\
\text { ptive narratives) with flow } \\
\text { diagrams } \\
\text { Analysis: focuses on } \\
\text { accountability and control } \\
\text { rather than SM }\end{array}$ \\
\hline \multicolumn{5}{|c|}{ (4) Socially Foregrounded Sociomaterial Accounts } \\
\hline $\begin{array}{l}\text { Jarrahi and Sawyer } \\
(2013)\end{array}$ & $\begin{array}{l}\text { Social } \\
\text { technologies and } \\
\text { informal } \\
\text { knowledge } \\
\text { practices }\end{array}$ & $\begin{array}{l}\text { Orlikowski (2002, } \\
2005,2006) ; \\
\text { Orlikowski and } \\
\text { Scott }(2008)\end{array}$ & $\begin{array}{l}\text { The conceptual basis is strongly } \\
\text { grounded in SM. }\end{array}$ & $\begin{array}{l}\text { Data: } 16 \text { pilot interviews } \\
\text { and } 54 \text { main interviews } \\
\text { Analysis: coding with the } \\
\text { aim of theory-building }\end{array}$ \\
\hline Oborn et al. (2013) & $\begin{array}{l}\text { Distributed } \\
\text { leadership as } \\
\text { sociomaterial } \\
\text { practice }\end{array}$ & $\begin{array}{l}\text { Mol (2002); } \\
\text { Orlikowski (2007); } \\
\text { Orlikowski and } \\
\text { Scott (2008); } \\
\text { Suchman (2007) }\end{array}$ & $\begin{array}{l}\text { SM perspective on distributed } \\
\text { leadership is developed and used to } \\
\text { frame the research. }\end{array}$ & $\begin{array}{l}\text { Data: ethnographic study } \\
\text { of policy formulation } \\
\text { supported by } 52 \text { interviews } \\
\text { and focus groups } \\
\text { Analysis: a mix of } \\
\text { inductive and deductive } \\
\text { methods }\end{array}$ \\
\hline
\end{tabular}


Table 1. Methodological Streams of Research Reporting Sociomateriality in 2013 (Continued)

\begin{tabular}{|c|c|c|c|c|}
\hline & $\begin{array}{l}\text { Research } \\
\text { Setting }\end{array}$ & $\begin{array}{l}\text { Theoretical } \\
\text { Grounding }\end{array}$ & Use of Sociomateriality & Research Method \\
\hline \multicolumn{5}{|c|}{ (4) Socially Foregrounded Sociomaterial Accounts (Continued) } \\
\hline $\begin{array}{l}\text { Panourgias et al. } \\
\text { (2013) }\end{array}$ & $\begin{array}{l}\text { Computer game } \\
\text { development, } \\
\text { creativity and } \\
\text { technology }\end{array}$ & $\begin{array}{l}\text { Barad (2007); } \\
\text { Orlikowski and } \\
\text { Scott }(2008)\end{array}$ & $\begin{array}{l}\text { The enquiry is framed by the } \\
\text { entanglement of things and people and } \\
\text { the co-development of gaming } \\
\text { experiences and technologies. }\end{array}$ & $\begin{array}{l}\text { Data: } 25 \text { interviews and } \\
\text { observation } \\
\text { Analysis: zooming in and } \\
\text { zooming out (Nicolini 2009) }\end{array}$ \\
\hline Porter (2013) & $\begin{array}{l}\text { Emergence of } \\
\text { organization and } \\
\text { technology in a } \\
\text { disaster situation }\end{array}$ & $\begin{array}{l}\text { Orlikowski (2007, } \\
\text { 2010); Leonardi } \\
\text { (2007); Barad } \\
(2007)\end{array}$ & $\begin{array}{l}\text { The enquiry is guided by SM and } \\
\text { situational boundary making. }\end{array}$ & $\begin{array}{l}\text { Data: } 22 \text { interviews, } \\
\text { participant observation, } \\
\text { email list-serve data } \\
\text { Analysis: grounded theory } \\
\text { techniques }\end{array}$ \\
\hline $\begin{array}{l}\text { Pritchard and Symon } \\
\text { (2013) }\end{array}$ & $\begin{array}{l}\text { Smartphones and } \\
\text { distributed work }\end{array}$ & $\begin{array}{l}\text { Feldman and } \\
\text { Orlikowski (2011); } \\
\text { Leonardi (2010); } \\
\text { Orlikowski and } \\
\text { Scott (2008) }\end{array}$ & $\begin{array}{l}\text { SM practices in knowledge sharing } \\
\text { frame the research design. }\end{array}$ & $\begin{array}{l}\text { Data: } 39 \text { interviews } \\
\text { Analysis: narrative } \\
\text { analysis (storytelling) }\end{array}$ \\
\hline Slade (2013) & $\begin{array}{l}\text { Professional } \\
\text { learning in rural } \\
\text { practice }\end{array}$ & $\begin{array}{l}\text { Fenwick (2010); } \\
\text { Gherardi and } \\
\text { Nicolini (2002) }\end{array}$ & $\begin{array}{l}\text { Practice-based learning and SM } \\
\text { approaches are used to frame the } \\
\text { research design. }\end{array}$ & $\begin{array}{l}\text { Data: } 11 \text { interviews and } 6 \\
\text { focus groups } \\
\text { Analysis: coding driven by } \\
\text { theory, prior research and } \\
\text { experience }\end{array}$ \\
\hline \multicolumn{5}{|c|}{ (5) Technology Foregrounded Sociomaterial Accounts } \\
\hline $\begin{array}{l}\text { De Vaujany et al. } \\
\text { (2013) }\end{array}$ & $\begin{array}{l}\text { Organizing } \\
\text { visions and trade } \\
\text { shows }\end{array}$ & $\begin{array}{l}\text { Johnson et al., } \\
\text { (2007); Orlikowski } \\
(2007)\end{array}$ & $\begin{array}{l}\text { SM is used to frame the investigation of } \\
\text { the fabric of organizing visions and IT- } \\
\text { related discourses within a practice- } \\
\text { based approach. }\end{array}$ & $\begin{array}{l}\text { Data: in-depth case study } \\
\text { with interviews, } \\
\text { observation, and } \\
\text { questionnaire } \\
\text { Analysis: qualitative and } \\
\text { quantitative analysis }\end{array}$ \\
\hline Stein et al. (2013) & $\begin{array}{l}\text { Identity and } \\
\text { technology in the } \\
\text { workplace }\end{array}$ & $\begin{array}{l}\text { Markus and Silver } \\
\text { (2008); Leonardi } \\
(2012)\end{array}$ & $\begin{array}{l}\text { SM is used to inform the analytical } \\
\text { framework used to guide the research, } \\
\text { taking a middle position between } \\
\text { idealism and materialism. }\end{array}$ & $\begin{array}{l}\text { Data: } 10 \text { interviews } \\
\text { supplemented with video- } \\
\text { recorded demonstrations } \\
\text { of technology use } \\
\text { Analysis: narrative } \\
\text { analysis (storytelling) }\end{array}$ \\
\hline
\end{tabular}

to capture the sociomaterial entangling "in action" (however, in this case, the paper does not include any detailed analysis of this video material per se). Indeed, as indicated by Table 1 , it is clear that methods used by authors who have not framed their empirical data collection up-front as sociomaterial are not inherently different from authors who have adopted this framing.

\section{Promising Developments in Methodology}

Table 1 highlights the point that several papers espouse a practice-based approach to sociomaterial research: DeVaujany et al. draw on Johnson et al. (2007); Slade draws on Gherardi and Nicolini (2002); Panourgias et al. use Nicolini (2009) to argue for zooming in and zooming out. Using a practice-based orientation and its associated zooming approach provides some interesting ideas about how we might extend qualitative research methods for IS investigations of sociomateriality.

In the practice-based approach, Gherardi (2012) allows technologies to be more vocal, adopting an "ethnography of objects" (Bruni 2005), which, she argues, enables us to study the performativity of technology as it emerges in situated practices. Gherardi provides numerous examples to illustrate this idea. For example, she cites Whalen et al. (2002), who describe the life-world of a call center, where professional 
competence is achieved "in and through interactional proficiency," with the technologies at-hand (Gherardi 2012, p. 99). Whalen et al. describe how the operators' practice is choreographed; for example, keeping a pad and pen to one side so that they can note the name of the caller they are responding to (since after the caller ID is input in the computer system it no longer appears on the screen). Simultaneously, they anticipate what the customer may ask by having ready-to-hand documents and pages on the computer that will allow a "competent performance — organized around a closely interrelated set of practical concerns...that requires an improvisational choreography of various means of action using different technologies and artifacts to carry off that performance" (Gherardi 2012, p. 99). In discussing these various studies that have identified the performativity of technology, Gherardi uses the concept of

an "equipped context" to examine how contexts are not simply neutral "containers" indifferent to ongoing actions that happen within them, but rather contexts are treated as a prepared environment that makes it easier to accomplish tasks because the context is "equipped" so as to elicit their habitual use (p. 98).

Here, she uses the example of rock climbing, where the rock "becomes somehow equipped to facilitate the climb if the climber regularly returns to the rock face or leaves pegs to help other climbers" (p. 97). Pollock and D'Adderio (2012) make a similar point when they talk about the "format and furniture" (in this case, of ranking devices that not only mediate but also constitute a domain of practice).

All of these examples illustrate how, to study sociomateriality, it is important to build/slice (dwell in) the sociomaterial world so that we can get sufficiently close to the practice at hand and recognize its material and embodied nature (Nicolini 2013) and so see "connections-in-action, as life-world and dwelling" (Gherardi 2012, p. 77). Such detailed ethnographies of nonhumans are still relatively rare in IS discourse where, as Table 1 demonstrates, we continue to rely on traditional interviews (and focus groups) with human subjects who are likely to privilege the role of human actors, rather than see agency as emerging from relations between human and nonhuman actors (i.e., the social and technological as mutually constitutive of our practice).

Adopting ethnographies of the nonhuman (or other methods that allow us to see up-close the material and embodied nature of practice) thus allows us to zoom in to examine sociomaterial practice, as indicated by the above examples of how call center operators can practice professionally in and through the various tools that are ready-to-hand, and how rock climbers operate in an equipped context. Such zooming-in to see connections-in-action is important, but we would argue that we should also adopt methods that allow us to study the dynamics of emergence. Many of the papers in Table 1 appear to present a relatively static picture of the sociomaterial world. This is why Nicolini (2013) advocates that we should also, simultaneously, zoom-out to discern the dynamic and emergent relationships between the social and material, since local practice is always affected by other (sociomaterial) practices removed in space and time (Latour 2005). The Gaskin et al. paper in this issue (described below) does exactly this, explicitly using a zooming-in and zooming-out approach. One way of studying this relational emergence through zooming-out is to study the same site over time (e.g., Huang et al. 2014), or different sites where the same practice is carried out. In this way we can "surface the effects produced by different nexuses of practice" (Nicolini 2013, p. 234). Again, we suggest that IS researchers could usefully examine more comparative cases of sociomaterial practices (as equipped contexts rather than neutral sites of practice), as well as conduct extended longitudinal studies, in order to better articulate how sociomaterial relations dynamically emerge through space and time. Some of the papers in this special issue, as described below, do this by making comparisons across contexts (e.g., Mazmanian et al.; Orlikowski and Scott) or across time (Jones).

Moreover, while our sociomaterial view of the world allows us to see how the material and social coproduce our (temporary) organizational arrangements, we also need to understand how newcomers moving into an already equipped context learn to use the technologies already in place when they are unfamiliar with them. ${ }^{8}$ So, while our experience in the world may be described as sociomaterial, with emergent consequences from the particular entanglement that, once familiar, can be observed as a choreographed performance, we need to examine how new users get to this point. Thus, while much IS research has focused on examining and explaining the factors influencing, the processes involved, and the consequences of introducing some new information system into an organizational context, very little research has examined how rookies become sociomaterially entangled when they first enter an (already) equipped context. The communities of practice literature (e.g., Lave and Wenger 1991) is clearly concerned with this issue, but most of this focuses on social processes, rather than examining the specific roles and consequences of technology as it affords and constrains the development of competent and choreographed sociomaterial practice.

\footnotetext{
${ }^{8}$ Slade (2013) specifically follows this route, but is the only such example that we were able to identify.
} 
While the idea of zooming-in and zooming-out using a toolkit of methods (Nicolini 2013), and the ethnography of objects in practice-based research, is helpful in conducting empirical studies that allow the particular relational ontological assumptions of a sociomaterial view to materialize in the data collected, we also need to find ways of representing the sociomaterial practice in text. As Nicolini indicates, this is not a trivial task because, while sociomaterial practices are everywhere, they "are famously recalcitrant when it comes to being transposed to text" (2013, p. 218). Our review of those recent studies that have adopted a sociomaterial lens, including the papers in this special issue, indicatesarguably - that they also struggle with this issue. Perhaps this is not surprising, since most of the theories and concepts that they draw on to articulate the sociomaterial themselves distinguish between the social and the material even while explaining agency as relationally produced. These theories and concepts include ANT, and the network of actors, with each actor being essentially social or material at least at one level of analysis; Pickering's "mangle," which distinguishes between (material) resistance and (human) accommodation; Leonardi's "imbrication," which distinguishes between material affordances and social adaptations; and Scott and Orlikowski's "entanglement," which nevertheless still "talks" in terms of individual social and material objects, albeit these are recognized as performative accomplishments rather than preexisting entities. In each case, agency may derive from the combination of the social and material actors involved, but we still tend to separate out the social and the material analytically and discursively in our texts.

\section{Greater Entanglement of Social and Material Is to Come}

This separation of the social and the material, we suggest, may be a problem of our "infra-language" (Latour 2005), which has not yet developed sufficiently to examine the sociomaterial. One concept that may help with this is the cyborg, a "hybrid of machine and organism" (Haraway 1991). We tend to associate cyborgs with science fiction movies, rather than as a useful metaphor that helps us in thinking about the sociomaterial reality of our everyday practice. Haraway (1991) was one of the first academics to use this metaphor in her feminist critique of capitalism. IS scholars, including sociomaterial scholars, have as yet to really engage with this metaphor, ${ }^{9}$ despite its potential to illustrate sociomaterial entanglement and the ways this produces or performs our life-world. The time is ripe to do so because we appear to

\footnotetext{
${ }^{9}$ The work of Ulrike Schultze being an exception (e.g., Schultze and Mason 2012).
}

be moving (and arguably have moved) to a life-world in which it may actually be difficult to separate the social and material, even in our everyday talk. For example, as we move to wearable computers, as in Google glasses or Apple watches, and as so much of what we do is digitized, we may "become our data" in ways that provide new opportunities for sociomaterial scholars to examine what Yoo (2013, p. 231) refers to as "digitally enabled generativity." In other words, it appears, potentially at least, that talking about social/ material entanglement will become easier as we actually become, increasingly, materially entangled cyborgs ourselves. For example, if we take the example of driving, our cars increasingly include tracking devices that monitor the person who is driving against information on the road they are driving (and so can detect speeding, wearing — or not-of seatbelts, and other simultaneous activities going on like mobile phone use); record the conditions of driving (and so can record what happened in an accident); are able to park themselves; and can automatically brake when coming too close to another object. In such instances, drivers and their cars are cyborgs and, importantly, data are collected in realtime and over time that allows us to study this cyborg (assuming we can gain access to such (big) data as these).

We can study the performativity of such entanglements in ways that would be more difficult when we could only interview a person about driving their car, observe that person driving intermittently, or see the consequences of their driving too fast. Now, we can see what the data tell us about this instance of cyborg existence, and we can manipulate the cyborg to produce different results. For example, perhaps we find that tracking software reduces speeding, while collision prevention software increases speeding, and the combination of the two technologies reduces speeding - suggesting that monitoring is more powerful than collision prevention in terms of its performative consequences. We might also find different outcomes for different populations, and so identify particular combinations of social and material entangling that produce different consequences. Studying the performativity of different entanglements may also help us to develop more nuanced sociomaterial theorizing.

Moreover, we can see in this cyborg example how practice is the outcome of the relationship between the social and the material, since the material or technical, at least in relation to the tracking of driving behavior, does not necessarily constrain driving behavior itself. Neither does it necessarily provide feedback in the moment as to whether a speed limit is being broken so that the human driver can adjust their speed. Rather, it is in the relationship between the "sensoredcar" and the driver - as a cyborg unit - that we can account for practice (and any emergence of this practice). In other words, as our existence becomes more obviously "cyborged," 
it also leaves a data trail (or data "exhaust," in the terminology of Mayer-Schönberger and Cukier 2013). It is this data trail that may well provide opportunities for analysis that can allow us more readily to examine sociomaterial performativity, without resorting solely to asking individuals (about people and their things) and observing and re-presenting them with our inherently limited non-sociomaterial vocabulary. Indeed, with the "datafication" of everything, we may get access to the doings of people and their tools (i.e., as cyborgs) in the moment, as well as across time and space. Research that draws on big data, then, may be useful for extending our sociomaterial theorizing because we then center our attention on the cyborg, rather than the social and the material, in each instance of practice that we track.

\section{Future Directions in Methodology}

A good example of such research is found in Pentland et al. (2011) in their use of data on invoice processing in four different organizations with a view to examining organizational routines. Their finding that there were many unique patterns generated by these routines, rather than just a few stable patterns, is illustrative of the emergence of which we have spoken, and of the more nuanced accounts that we seek. We suggest that IS researchers can achieve significant insights that help us to develop our sociomaterial theorizing using these big data sets. For example, the paper by Gaskin and his colleagues in this issue argues that, while sociomaterial routines can be studied using a lexicon and data traces, these trace data must be triangulated with detailed and idiographic local accounts of activity, leading to a blurring of the line between qualitative and quantitative approaches. The authors argue that such an approach is not simply mixed methods research (see Mingers 2001). Rather, it is a flexible computational approach, not a quantitative one-one that represents a "third-wave" methodology. Hedman et al. (2013, p. 17) take the digital trace/idiographic categories and propose a two-by-two matrix (with the dimensions subjective/ objective and digitalized/non-digitalized) to take into account trace data and interpretive accounts. These third-wave methodologies take advantage of digital traces and computation to undertake super-large analyses involving thousands of routines and tens of thousands of activities - data volumes that cannot be tackled by human effort alone-while recognizing the local, interpretive, and situated nature of sociomaterial activity.

Another promising methodology for future sociomaterial inquiry is inspired by, and draws from, practice-oriented scholarship that takes practice as epistemology (Gherardi 2012). A practice-oriented sociomaterial methodology does not approach practice as an empirical object from a bird's eye view, but instead explores practice as a material-discursive field of action by zooming-in and zooming-out iteratively (Nicolini 2013). Practice as epistemology, to use Nicolini's expression, is "rhisomatic in nature" (p. 238): a study begins as an in-depth inquiry in one location (zooming in) and then expends to other locations by following emerging relations (zooming out); zooming in then continues in new locations. This iterative process follows relations and concurrently engages in real-time shadowing of heterogeneous entities performed by the relations, which unpredictably takes researchers to unexpected places and situations (see Bruni et al. 2007; Star 2010). The objective is to develop an appreciation and articulate the dynamics of practice by observing and experiencing from different angles and perspectives how entities, people and technologies, their boundaries, properties and identities, are continuously performed, what the consequences are and for whom. ${ }^{10}$ In other words, this rhisomatic methodology allows and motivates an insight into how reality is made and re-made from diverse standpoints and beyond a particular locale, thus paying attention not only to local but also to trans-local effects. It is important to note, however, that practice as epistemology is not a ready-made methodology that one can apply as a script, step by step. It is a research philosophy as much as a methodology, one that often involves experimentation, improvisation, and critical reflection (Gherardi 2012). While long and rich ethnographic tradition (e.g., Locke 2011) and ethnomethodology studies (Garfinkel 1967) are showing us a way, practice as epistemology poses new challenges about which we are yet to learn, and with which we are yet to deal.

We next turn to a consideration of the articles selected for this special issue, relating them (in Table 2) to the points of discussion covered above - that is, the particular sociomaterial perspective adopted and the methods used.

\section{Articles in the Special Issue}

Our call for papers stimulated considerable interest, with more than 80 submissions being received. Five of the submissions successfully went through three or more rounds of revision and appear in this special issue. Table 2 offers an overview of the articles that we accepted, in terms of their focus, perspective, methods employed, and contribution. We briefly introduce them here by discussing their take on the sociomateriality of information systems and organizing.

\footnotetext{
${ }^{10}$ This is reminiscent of Foucault (1978) who renounces an assumed sovereign standpoint above the fray from which knowledge claims are made and thus seen as legitimate.
} 
Table 2. Contributions

\begin{tabular}{|c|c|c|c|c|c|}
\hline Title & Authors & Focus & $\begin{array}{l}\text { Sociomaterial } \\
\text { Perspective }\end{array}$ & Methods & Contribution \\
\hline $\begin{array}{l}\text { Dynamic } \\
\text { Reconfiguration } \\
\text { in Planetary } \\
\text { Exploration: A } \\
\text { Sociomaterial } \\
\text { Ethnography }\end{array}$ & $\begin{array}{l}\text { Mazmanian, } \\
\text { Cohn, and } \\
\text { Dourish }\end{array}$ & $\begin{array}{l}\text { The dynamics of } \\
\text { mutual constituency of } \\
\text { social and material } \\
\text { arrangements as it } \\
\text { plays out in the practice } \\
\text { of NASA scientists. }\end{array}$ & $\begin{array}{l}\text { Drawing on feminist } \\
\text { scholarship in science and } \\
\text { technology studies, the } \\
\text { article advances a dynamic } \\
\text { reconfiguration } \\
\text { perspective. }\end{array}$ & $\begin{array}{l}\text { Nine months of ethno- } \\
\text { graphic fieldwork } \\
\text { including interviews } \\
\text { (oral history interviews } \\
\text { and software walk- } \\
\text { throughs and dia- } \\
\text { graming) and obser- } \\
\text { vations (work shad- } \\
\text { owing, trace observa- } \\
\text { tions, and participant } \\
\text { observation). }\end{array}$ & $\begin{array}{l}\text { The article offers a } \\
\text { new perspective, } \\
\text { dynamic reconfigura- } \\
\text { tion, for studying } \\
\text { sociomateriality in } \\
\text { information systems } \\
\text { and organization } \\
\text { studies. }\end{array}$ \\
\hline $\begin{array}{l}\text { Toward } \\
\text { Generalizable } \\
\text { Sociomaterial } \\
\text { Inquiry: A } \\
\text { Computational } \\
\text { Approach for } \\
\text { Zooming In and } \\
\text { Out of } \\
\text { Sociomaterial } \\
\text { Routines }\end{array}$ & $\begin{array}{l}\text { Gaskin, } \\
\text { Berente, } \\
\text { Lyytinen, } \\
\text { and Yoo }\end{array}$ & $\begin{array}{l}\text { An approach to } \\
\text { sociomaterial inquiry } \\
\text { that is intended to be } \\
\text { scalable across } \\
\text { multiple contexts and } \\
\text { thus complements the } \\
\text { dominant idiographic } \\
\text { approaches that focus } \\
\text { on particular contexts. }\end{array}$ & $\begin{array}{l}\text { The computational } \\
\text { approach is founded on } \\
\text { sequence-analytic } \\
\text { techniques that originated } \\
\text { from the field of } \\
\text { computational biology } \\
\text { (genetics) and are now } \\
\text { being applied in the study } \\
\text { of temporally ordered } \\
\text { social phenomena such as } \\
\text { organizational routines. } \\
\text { These techniques are } \\
\text { extended by drawing on } \\
\text { theoretical insights gained } \\
\text { from research into } \\
\text { sociomateriality with regard } \\
\text { to how the digital and the } \\
\text { social become entangled. }\end{array}$ & $\begin{array}{l}\text { A computational, } \\
\text { mixed methods ap- } \\
\text { proach that combines } \\
\text { qualitative analysis } \\
\text { and sequence analy- } \\
\text { sis for studying the } \\
\text { entanglement of } \\
\text { human activities and } \\
\text { digital capabilities in } \\
\text { organizational } \\
\text { routines. }\end{array}$ & $\begin{array}{l}\text { The approach } \\
\text { advocated provides } \\
\text { researchers with a } \\
\text { means to seek and } \\
\text { uncover regularities } \\
\text { in the ways human } \\
\text { activities and digital } \\
\text { capabilities become } \\
\text { entangled across } \\
\text { contexts by enabling } \\
\text { the identification and } \\
\text { articulation of gener- } \\
\text { alizable patterns of } \\
\text { sociomaterial } \\
\text { activity. }\end{array}$ \\
\hline $\begin{array}{l}\text { Entanglements in } \\
\text { Practice: } \\
\text { Performing } \\
\text { Anonymity } \\
\text { Through Social } \\
\text { Media }\end{array}$ & $\begin{array}{l}\text { Scott and } \\
\text { Orlikowski }\end{array}$ & $\begin{array}{l}\text { The entanglement of } \\
\text { meaning and } \\
\text { materiality in the } \\
\text { enactment of } \\
\text { anonymity in the } \\
\text { practices of evaluation } \\
\text { and ranking in the } \\
\text { hospitality industry; it is } \\
\text { concerned with } \\
\text { performative effects of } \\
\text { different material } \\
\text { enactments of } \\
\text { anonymity for issues of } \\
\text { verification and } \\
\text { accountability. }\end{array}$ & $\begin{array}{l}\text { The paper advances the } \\
\text { sociomaterial approach } \\
\text { based on relational } \\
\text { ontology and performa- } \\
\text { tivity; it draws from Barad's } \\
\text { (2007) agential realism } \\
\text { demonstrating how its key } \\
\text { concepts- entanglement, } \\
\text { material-discursive } \\
\text { practices, agential cuts, } \\
\text { and performativity- can be } \\
\text { productively used to } \\
\text { examine materiality of } \\
\text { social media and user- } \\
\text { generated content. }\end{array}$ & $\begin{array}{l}\text { Two-year field study } \\
\text { of hotel evaluation } \\
\text { practices in the UK- } \\
\text { based AA scheme } \\
\text { and the online social } \\
\text { media based } \\
\text { TripAdvisor; the study } \\
\text { includes interviews, } \\
\text { field observations, } \\
\text { documents, and } \\
\text { archival material; data } \\
\text { analysis comprises } \\
\text { several rounds of } \\
\text { coding focusing on } \\
\text { material-discursive } \\
\text { practices and the } \\
\text { production of } \\
\text { anonymity. }\end{array}$ & $\begin{array}{l}\text { The paper contrib- } \\
\text { utes a novel under- } \\
\text { standing of anony- } \\
\text { mity as enacted } \\
\text { accomplishment } \\
\text { entangled with } \\
\text { specific material- } \\
\text { discursive practices } \\
\text { of hotel evaluation; } \\
\text { the paper illustrates } \\
\text { how an agential } \\
\text { realist account } \\
\text { enables new insights } \\
\text { into the ways dif- } \\
\text { ferent enactments of } \\
\text { anonymity generate } \\
\text { different agential } \\
\text { cuts-specific hotel } \\
\text { rankings and their } \\
\text { performative effects } \\
\text { on the hospitality } \\
\text { industry. }\end{array}$ \\
\hline
\end{tabular}


Table 2. Contributions (Continued)

\begin{tabular}{|c|c|c|c|c|c|}
\hline Title & Authors & Focus & $\begin{array}{l}\text { Sociomaterial } \\
\text { Perspective }\end{array}$ & Methods & Contribution \\
\hline $\begin{array}{l}\text { A Matter of Life } \\
\text { and Death: } \\
\text { Exploring Con- } \\
\text { ceptualizations of } \\
\text { Sociomateriality } \\
\text { in the Context of } \\
\text { Critical Care }\end{array}$ & Jones & $\begin{array}{l}\text { The introduction of a } \\
\text { clinical information } \\
\text { system (CIS) in a } \\
\text { critical care unit of a } \\
\text { hospital in order to } \\
\text { examine how a range } \\
\text { of key sociomaterial } \\
\text { themes offer distinctive } \\
\text { insights to the on-going } \\
\text { and changing practices } \\
\text { in this setting, in } \\
\text { particular with regard to } \\
\text { the relationships } \\
\text { between the social and } \\
\text { the material. }\end{array}$ & $\begin{array}{l}\text { The paper uses } 5 \text { distinct } \\
\text { sociomaterial notions } \\
\text { derived from the work of } \\
\text { Orlikowski (materiality, } \\
\text { inseparability, relationality, } \\
\text { performativity, and } \\
\text { practices) and considers } \\
\text { what each can shed light } \\
\text { on individually and } \\
\text { collectively. Also illustrates } \\
\text { that each notion can be } \\
\text { viewed from a distinct onto- } \\
\text { logical position that } \\
\text { provides distinct (but } \\
\text { potentially equally valid) } \\
\text { insights. }\end{array}$ & $\begin{array}{l}\text { Case study beginning } \\
6 \text { months before the } \\
\text { introduction of a CIS } \\
\text { and continuing } 9 \\
\text { months after adoption } \\
\text { of the CIS in an ICU } \\
\text { unit. Data collection } \\
\text { included observations, } \\
\text { interviews and docu- } \\
\text { ment gathering. Data } \\
\text { analyzed according to } \\
\text { the five previously } \\
\text { identified key notions } \\
\text { of the sociomaterial } \\
\text { perspective. }\end{array}$ & $\begin{array}{l}\text { The paper con- } \\
\text { tributes to the argu- } \\
\text { ment that a socio- } \\
\text { material perspective } \\
\text { can offer unique } \\
\text { insights into the rela- } \\
\text { tionship between the } \\
\text { social and the } \\
\text { material but only if } \\
\text { authors pay greater } \\
\text { attention to the key } \\
\text { notions entailed in } \\
\text { the concept, and } \\
\text { recognize their dif- } \\
\text { ferent interpreta- } \\
\text { tions. Case study } \\
\text { also contributes to } \\
\text { our understanding of } \\
\text { different forms of } \\
\text { sociomateriality. }\end{array}$ \\
\hline $\begin{array}{l}\text { A Trichordal } \\
\text { Temporal } \\
\text { Approach to } \\
\text { Digital Coordi- } \\
\text { nation: The } \\
\text { Sociomaterial } \\
\text { Mangling of the } \\
\text { CERN Grid }\end{array}$ & $\begin{array}{l}\text { Venters, } \\
\text { Oborn, and } \\
\text { Barrett }\end{array}$ & $\begin{array}{l}\text { The use and develop- } \\
\text { ment of a computing } \\
\text { grid infrastructure that } \\
\text { supports analysis of the } \\
\text { massive volumes of } \\
\text { data generated by the } \\
\text { Large Hadron Collider } \\
\text { at CERN. The grid is } \\
\text { extensive and is main- } \\
\text { tained by a group of } \\
\text { computing specialists. } \\
\text { A large community of } \\
\text { particle physicists } \\
\text { submit analysis jobs to } \\
\text { the grid. Together this } \\
\text { results in a challenge } \\
\text { for digital coordination. }\end{array}$ & $\begin{array}{l}\text { To investigate digital coor- } \\
\text { dination, the temporal } \\
\text { aspects of Pickering's } \\
\text { mangle of practice are } \\
\text { developed further using } \\
\text { Emirbayer and Mische's } \\
\text { (1998) trichordal temporal } \\
\text { approach - a chordal triad } \\
\text { of agency in which the } \\
\text { past, present, and future } \\
\text { are viewed as dynamically } \\
\text { constituted, emergent, and } \\
\text { inseparable. }\end{array}$ & $\begin{array}{l}\text { An in-depth case from } \\
2006 \text { to } 2010 \text { that } \\
\text { studies the use of a } \\
\text { computing grid by } \\
\text { particle physicists } \\
\text { preparing for the } \\
\text { launch of the Large } \\
\text { Hadron Collider. Data } \\
\text { collection includes } \\
\text { interviews, ethnog- } \\
\text { raphic observation, } \\
\text { and reviews of docu- } \\
\text { ments. Data are } \\
\text { analyzed using } \\
\text { Pickering's mangle of } \\
\text { practice with trichordal } \\
\text { extensions. }\end{array}$ & $\begin{array}{l}\text { A contribution of the } \\
\text { paper is to show the } \\
\text { inseparability of past, } \\
\text { present, and future } \\
\text { and to demonstrate } \\
\text { how a trichordal } \\
\text { temporal perspective } \\
\text { gives deeper insight } \\
\text { into the mangle. By } \\
\text { situating digital infra- } \\
\text { structure in the flow } \\
\text { of time the dynamic } \\
\text { aspects of digital } \\
\text { coordination are } \\
\text { highlighted and } \\
\text { implications for infra- } \\
\text { structure manage- } \\
\text { ment are identified. }\end{array}$ \\
\hline
\end{tabular}

Melissa Mazmanian, Marisa Cohn, and Paul Dourish provide a new perspective, which they call dynamic reconfiguration, for studying sociomateriality in information systems and organizing. This perspective offers a language with which to appreciate the dynamic nature by which technologies and social structures reconfigure each other. It derives from a detailed ethnography of planetary exploration at NASA that involved interviews (oral history interviews, software walkthroughs, and diagraming) and observations (work shadowing, trace observations, and participant observation). In particular, the authors explore a mission orbiting an outer planet in the solar system. They use three empirical examples of reconfiguration practice as the spacecraft is navigated, material breakdowns are accounted for, and individuals tinker to ensure that critical software is working. Drawing on feminist scholarship in science and technology studies (Barad 2003; Cetina 1999; Haraway 1997; Suchman 2007), this material is used to frame the dynamics of mutual constituency of social and material arrangements as it plays out in practice by NASA scientists. The dynamic reconfiguration perspective is delineated from what the authors refer to as separation, symmetry, and shaping perspectives of sociomaterial scholarship.

The second article, by James Gaskin, Nicholas Berente, Kalle Lyytinen, and Youngjin Yoo, invites us to consider raising our sights away from a focus on the idiosyncrasies of local practices to the kind of general theorizing that is advocated by 
Giddens (1984), and the kind of comparative research that we envisioned earlier in this editorial. As we noted earlier, their computational approach for zooming in and out of sociomaterial routines marks a distinct turn away from the norm of sociomaterial enquiry to date. The authors argue that focusing our enquiries solely into "local negotiations...may overlook what might be common patterns of activity and sociomaterial associations across multiple contexts" (p. 850). They draw on the likes of Bourdieu (1977) to make the point that "local practices, no matter how unique and creative, draw upon and enact inherited, structural properties of habitualized patterns of action" (p. 850). Thus, they argue for an approach that enables the consideration of broader, general patterns. In doing this, the authors combine interpretive, qualitative analysis with a computational approach to sequence analysis in what is a novel means of undertaking research into "the entanglement of human activities and digital capabilities in organizational routines" (p. 849) across different contexts. They first introduce a lexicon to describe sociomaterial routines and then go on to describe the steps of what they describe as a reconstructive approach (see Habermas 1979) to the analysis of those routines. Having discussed questions of the approach's validity and reliability, they consider its potential benefits and limitations before concluding with a reflection on how to advance generalizable sociomaterial research of this kind into the future.

The Gaskin et al. article is included not just for its methodological novelty. The opportunity to broaden our horizons in sociomaterial discourse across organizational boundaries and to reconsider what might be taken-for-granted assumptions about the nature of sociomaterial inquiry is a step in further opening up debate of the kind to be found in a recent issue of the journal Information \& Organization (volume 23, 2013) and in Leonardi's (2012) consideration of the concepts associated with materiality, sociomateriality, and sociotechnical systems. Indeed, citing Trist and Bamforth (1951), Gaskin et al. make the point that they "do not draw a hard line between the sociomaterial position and the sociotechnical tradition" ( $p$. 851). This, in and of itself, should cause some further reflection and not a little debate in the academy. In their opinion,

the sociomaterial view fulfills and perhaps matures the sociotechnical tradition with an emphasis on practice rather than systems [adding] nuance in some areas [such as] ontological inseparability in practice, material agency, [and] social construction (p. 851).

As already noted, Orlikowski and Scott (2008) argue that sociomateriality is an umbrella term; whether they would go so far as to view this contribution by Gaskin et al. as mere maturing of the sociotechnical tradition is another matter, however.
Susan Scott and Wanda Orlikowski contribute to this special issue with their article "Entanglement in Practice: Performing Anonymity Through Social Media." In it, they build on and extend the sociomaterial perspective they have promoted and expounded over the last several years (Orlikowski 2007, 2010; Orlikowski and Scott 2008, 2013; Scott and Orlikowski 2012). They make it clear that their original proposal for a sociomaterial perspective does not imply a particular theoretical foundation. However, in their empirical work, they develop a particular sociomaterial perspective that is grounded in agential realism, following Barad (1998, 2003, 2007).

Scott and Orlikowski explore the notion of entanglement of meaning and materiality in the practices of evaluation and ranking in the hospitality industry. Based on a two-year field study, they conduct an in-depth examination of anonymity as performed by mystery guests in the UK-based AA evaluation system, and online by actual guests on the TripAdvisor website (a form of crowd-sourced content). They provide a detailed account of how anonymity is constituted by ongoing material-discursive practices in each. While the anonymity of an AA inspector (a mystery guest) is critical during the stage of experiencing the hotel and its facilities (as with regular guests), an inspector's identity is revealed in the rest of the evaluation process. In contrast, assessments of various hotel features and comments about experience that a hotel guest posts on the TripAdvisor website is anonymous, with questions regarding verification and accountability remaining problematic and contested. Attending to the intricacies of these two apparatuses of hotel evaluation, the authors show how anonymity is differentially enacted through specific entanglements of meaning and materiality, with significant performative consequences for the travel sector.

While anonymity in the literature has been considered predominantly a social phenomenon (as a singular and static property of an agent or state of a system), Scott and Orlikowski argue that anonymity is an enacted accomplishment that is multiple, dynamic, and sociomaterial. Their insight into the entanglement of specific material-discursive practices and enactments of anonymity shows how these practices generate different agential cuts: specific hotel rankings and their performative effects. Of particular concern is the lack of verification and accountability in the material enactment of anonymity in online user-generated content, and how such exclusion participates in the generation of specific consequences (i.e., hotel rankings). This analysis has broader implications for openness and accountability of new organizational forms based on social media and crowd-sourced content as their materiality becomes enfolded in everyday practices of knowledge production and consumption. 
Matthew Jones's paper, “A Matter of Life and Death: Exploring Conceptualizations of Sociomateriality in the Context of Critical Care," asks us to reflect on how the sociomateriality concept can be used in IS research to improve our understanding of how the social and the material - togetherproduce and reproduce ongoing forms of organizing. Demonstrating that the term was introduced to the field of IS through a number of papers by Orlikowski, Jones begins by unpacking the key notions that Orlikowski subscribes to sociomateriality, suggesting that this reveals five distinct (but interrelated) central ideas: materiality, inseparability, relationality, performativity, and practices. Jones's review of recent literature reveals that very few papers have engaged with more than one or two of these key notions, with most being "somewhat selective in their reading of Orlikowski's work" (p. 896), focusing mainly on using the term to emphasize how our past IS accounts have underplayed the role of material objects themselves in producing consequences.

Based on his review of the literature, Jones sets out to apply these key notions in a study of the implementation and use of a new clinical information system (CIS) in a critical care unit (CCU) of a specialist UK cardiothoracic hospital. For each notion, he produces a range of ways (or forms, to use his term) in which each notion was manifest in the new CISenabled setting, demonstrating how each contributes to our understanding of how, why, and with what consequences practice changed as the result of newly emergent relations between the social and the material in this setting. Jones emphasizes that it is possible to produce different accounts, using the same notions and so contrasts a strong and a weak sociomateriality. For example, a strong sociomateriality assumes a fully relational ontology, where entities exist only in relation to other entities, so that organizing is always in a state of becoming. Conversely, a weak sociomateriality suggests that entities exist independently of their enactment in practice, even while it is through relations between entities that agency can be explained. Jones suggests that these differences may be a product of the scale and scope of analysis that is considered, with strong sociomaterialists focused on micro-processes, and weak sociomaterialists interested in more enduring macro-level patterns. This leads Jones to conclude that "it may be possible to agree that IS phenomena involve an entanglement of the social and material that is enacted in situated practice, while adopting quite different ontological assumptions" (p. 920).

In the final paper in this special issue, Will Venters, Eivor Oborn, and Michael Barrett seek to understand the emergence of a computing grid that is used to support the storage and analysis of data gathered by the Large Hadron Collider at CERN. The case study reports on a truly large installation- the data volumes are vast (15 million gigabytes of data a year), the processing requirements intense (utilizing 150,000 computers), and the community is huge (around 3600 particle physicists). The case spans the period 2006-2010 and involves a large number of interviews, ethnographic observations, and source documents. To investigate the emergence of the grid and the problem of digital coordination, the authors develop Pickering's (1995) mangle of practice concept by elaborating on the temporal dimension. Pickering defines tuning as a process in which material agency is harnessed within a flow of material agency through an emerging dialectic in which the human and the material are enmeshed and constitutively entangled. Venters et al. argue that greater understanding of the temporal aspects of Pickering's mangle can be gained by applying Emirbayer and Mische's (1998) chordal triad of agency (i.e., that, at any given moment, agency is oriented toward the past, present, and future). Their analysis of the data brings out temporal tensions in digital coordination: transparency in the present, modeling future infrastructures, and the historical disciplining of social and material inertia. Venters et al. demonstrate that digital infrastructure is oriented to multiple dimensions of time: while infrastructure may emerge in the present, it is entangled with orientations to the past and future.

\section{Implications and Looking Forward}

Having covered the philosophy and roots of sociomaterial theorizing, as well as having reviewed current theoretical accounts and methodological approaches adopted under the umbrella of sociomateriality, including those in this special issue, in this last section, we suggest four possible opportunities for future research that can usefully extend our understanding of information systems through examination of the constitutive entanglement between human and material actors:

1. Focusing on ethical and social responsibility issues: Recognizing the co-constitution between the social and the technical does not imply equality. In our increasingly digitized world, the data collected, and the algorithms used to make decisions based on these data, have performativity. In other words, they produce a lived experience that could be/is becoming very different from our past/ current experience, changing the knowledge/power dynamics of everyday life (see Yoo 2010). Technologies (produced from prior social and material entanglements) have always constrained, as well as afforded, current (and future) opportunities. In other words, technologically enabled opportunities are not given, but are 
performed. Adopting a sociomaterial lens suggests that we need to acknowledge and examine the non-neutral performative implications of this co-constitution and accountability of those involved (including researchers). Do we want to live in a world that is produced by an ever-more elaborate set of algorithms that proscribe the outcomes of our search, the decisions made about who should get mortgages, how much insurance should be paid, what advertisements we view, what health procedures are undertaken, and so on? Examining this nonneutral (i.e., knowledge/power) performativity of social and technological entanglements, and more generally of information systems, for society at large and the organizations that co-constitute this society, implies an ethical dimension that is hugely important in our view.

2. Studying flows (process/becoming ontology): As we have seen, there is debate within the community of scholars who label themselves as sociomaterialists about whether entities (social and material) preexist, or only exist in and through relations. Nevertheless, arguably, the more important ontological foundation of sociomateriality (that all agree on) is that it assumes a becoming ontology: all things and events are in a constant state of emergence and that stability is achieved only temporarily if at all. However, in our empirical studies, we are only able to account for stability by putting in place arbitrary time/space boundaries and then, within this cut, deciding on which entities and attributes to focus. The implication of this ontological observation is that we need to be more aware of, and reflexive about, the cuts that we make (even when collecting longitudinal data) when we decide to conduct a particular study. This is so because there is always an interpenetration between the past/present/future (Henfridsson and Yoo 2013). Ignoring how the past and future are present in the present undermines our ability to account sufficiently for what we find in our data. Attending to dynamic, unfolding processes also has implications for a unit of analysis that is not fixed and given in advance but instead emerges together with an inquiry.

3. Identifying new methodologies that allow the (socio)material to speak for itself: Methodologically, as we have argued, we need to identify new ways to study the flows of social and material entanglement, especially using methods that do not rely solely on social actors to account for how the technology is acting in complex assemblages, in order to overcome the human-centric view of our world that has largely dominated in the social sciences, including the IS field. We have suggested some ways of allowing the technology to speak for itself and also identified new opportunities emerging with practice as epistemology and, more generally, practiceoriented scholarship. We hope that other methodologies will be developed and used that can overcome the linguistic limitations that tend to push us toward dividing up the world into discrete objects and events.

4. Being practically relevant: The focus on the epistemological and ontological aspects of a sociomaterial lens has arguably produced a body of literature that is even less accessible and relevant to the everyday person than is much of our academic literature (which is in any case criticized for not having practical and/or societal relevance or impact ${ }^{11}$ ). Given the roots of sociomateriality in a practice perspective, with its focus on the everyday lived experience, it is perhaps ironic that it has, to date, very little to offer the practitioner. (After all, how many practitioners are going to be able to make any sense of, never mind care about, whether we adopt a critical realist or an agential realist ontology, and so on?) We, therefore, advocate spending more time and energy on identifying the practical implications associated with understanding the co-constitution of the social and the material and the performative role of technologies (i.e., recognizing the non-neutral implications of complex technologically imbricated assemblages) developed and implemented.

We trust that this special issue on the sociomateriality of information systems has helped in some small way to frame and advance our understanding of this complex and emerging topic, and to propose an agenda for the field of IS moving forward. Given the increasingly sociomaterial entanglement of the world in which we live, we believe that this focus can be extremely relevant both theoretically and practically, and that the papers selected in this special issue help to further this agenda.

Finally, as the editors of this special issue, we would like to thank all those who submitted papers, the associate editors (Karen Barad, Michael Barrett, Nick Berente, Brian Butler, Robert Davison, Bill Doolin, Samar Faraj, Rick Iedema, Matthew Jones, Robert B. Johnston, Giovan Francesco Lanzara, Paul Leonardi, John Mingers, Jodie Moll, Eric Monteiro, Jan Mouritsen, Davide Nicolini, Daniel Nyberg, Ted O'Leary, Wanda Orlikowski, Neil Pollock, Neil Ramiller, Susan Scott, Lucy Suchman, Eileen Trauth, Erica Wagner, and Youngjin Yoo), and, finally, the many anonymous reviewers who worked so hard to select and develop the papers that constitute this special issue.

\footnotetext{
${ }^{11}$ See, for example, the work of Desouza and his colleagues $(2006,2007)$.
} 


\section{References}

Avison, D., Bjørn-Andersen, N., Coakes, E., Davis, G. B., Earl, M. J., Elbanna, A., Fitzgerald, G., Galliers, R. D., Hirschheim, R., Iivari, J., Klein, H. K., Land, F., de Marco, M., Pettigrew, A. M., Porra, J., Stahl, B. C., Sørensen, C., Wood, B., and WoodHarper, T. 2006. "Enid Mumford: A Tribute," Information Systems Journal (16:4), pp. 343-382.

Bansal, P., and Knox-Hayes, J. 2013. "The Time and Space of Materiality in Organizations and the Natural Environment," Organization \& Environment (26:1), pp. 61-82.

Barad, K. 1998. "Getting Real: Technoscientific Practices and the Materialization of Reality," Differences: A Journal of Feminist Cultural Studies (10:2), pp. 88-128.

Barad, K. 2003. "Posthumanist Performativity: Toward an Understanding of How Matter Comes to Matter," Signs: Journal of Women in Culture and Society (28:3), pp. 801-831.

Barad, K. 2007. Meeting the Universe Halfway: Quantum Physics and the Entanglement of Matter and Meaning, Durham, NC: Duke University Press.

Benbasat, I., and Zmud, R. W. 2003. "The Identity Crisis Within the IS Discipline: Defining and Communicating the Discipline's Core Properties," MIS Quarterly (27:2), pp. 183-194.

Bjørn-Andersen, N., Earl, M., Holst, O., and Mumford, E. 1982. Information Society: For Richer, for Poorer, Amsterdam: North-Holland.

Boos, D., Guenter, H., Grote, G., and Kinder, K. 2013. "Controllable Accountabilities: The Internet of Things and its Challenges for Organizations," Behavior \& Information Technology (32:5), pp. 449-467.

Bourdieu, P. 1977. Outline of a Theory of Practice, Cambridge, UK: Cambridge University Press.

Bruni, A. 2005. "Shadowing Software and Clinical Record: On the Ethnography of Non-Humans," Organization (12:3), pp. 357-378.

Bruni, A., Gherardi, S., and Parolin, L. 2007. "Knowing as a System of Fragmented Knowledge," Mind, Culture and Activity (14:1-2), pp. 83-102.

Callon, M. 1986a. 'The Sociology of an Actor-Network: The Case of the Electric Vehicle," in Mapping the Dynamics of Science and Technology, M. Callon, J. Law, and A. Rip (eds.), London: MacMillan Press, pp. 19-34.

Callon, M. 1986b. "Some Elements of a Sociology of Translation: Domestication of the Scallops and the Fishermen of Saint Brieuc Bay," in Power, Action and Belief: A New Sociology of Knowledge? Sociological Review Monograph (32), J. Law (ed.), London: Routledge and Kegan Paul, pp. 196-233.

Callon, M. 1999. "Actor-Network Theory: The Market Test," in Actor-Network Theory and After, J. Law and J. Hassard (eds.), Oxford, UK: Blackwell and the Sociological Review, pp. 181-195.

Carlile, P. R., Nicolini, D., Langley, A., and Tsoukas, H. (eds.). 2013a. How Matter Matters: Objects, Artifacts, and Materiality in Organization Studies, Oxford, UK: Oxford University Press.

Carlile, P. R., Nicolini, D., Langley, A., and Tsoukas, H. 2013b "How Matter Matters: Objects, Artifacts, and Materiality in Organization Studies-Introducing the Third Volume of Per- spectives on Organization Studies," in How Matter Matters: Objects, Artifacts, and Materiality in Organization Studies, P. R. Carlile, D. Nicolini,, A. Langley, and H. Tsoukas (eds.), Oxford, UK: Oxford University Press, pp. 1-15.

Cecez-Kecmanovic, D., Kautz, K., and Abrahall, R. 2014. "Reframing Success and Failure of Information Systems: A Performative Perspective," MIS Quarterly (38:2), pp. 561-588.

Cetina, K. K. 1999. Epistemic Cultures: How the Sciences Make Knowledge, Boston: Harvard University Press.

Desouza, K. C., El Sawy, O. A., Galliers, R. D., Loebbecke, C., and Watson, R. T. 2006. "Beyond Rigor and Relevance Towards Responsibility and Reverberation: Information Systems Research that Really Matters," Communications of the Association for Information Systems (17:16), pp. 341-353.

Desouza, K. C., Ein-Dor, P., McCubbrey, D. J., Galliers, R. D., Myers, M. D., and Watson, R. T. 2007. "Social Activism in Information Systems Research: Making the World a Better Place," Communications of the Association for Information Systems (19:13), pp. 261-277.

De Vaujany, F. X., Carton, S., Dominguez-Pery, C., and Vaast, E. 2013. "Moving Closer to the Fabric of Organizing Visions: The Case of a Trade Show," Journal of Strategic Information Systems (22:1), pp. 1-25.

Elias, N. 1978. What Is Sociology? (trans. by S. Mennel and G. Morrissey), New York: Columbia University Press.

Emirbayer, M. 1997. "Manifesto for a Relational Sociology," American Journal of Sociology (103:2), pp. 281-317.

Emirbayer, M., and Mische 1998. "What Is Agency?," American Journal of Sociology (103:4), pp. 962-1023.

Faulkner, P., and Runde, J. 2012. "On Sociomateriality," in Materiality and Organizing: Social Interaction in a Technological World, P. M. Leonardi, B. A. Nardi, and J. Kallinikos (eds.), Oxford, UK: Oxford University Press, pp. 49-66.

Fenwick, T. 2010. "Re-thinking the 'Thing': Sociomaterial Approaches to Understanding and Researching Learning in Work," Journal of Workplace Learning (22:1/2), pp. 104-116.

Ferguson, J., Soekijad, M., Huysman, M., and Vaast, E. 2013. "Blogging for ICT4D: Reflecting and Engaging with Peers to Build Development Discourse," Information Systems Journal (23:4), pp. 307-328.

Feldman, M. S., and Orlikowski, W. J. 2011. "Theorizing Practice and Practicing Theory," Organization Science (22:5), pp. 1240-1253.

Foucault, M. 1978. The History of Sexuality, Volume 1 (trans. R. Hurley), New York: Random House.

Garfinkel, H. 1967. Studies in Ethnomethodology, Englewood Cliffs, NJ: Prentice Hall.

Gaskin, James, Berente, N., Lyytinen, K., and Yoo, Y. 2014. "Toward Generalizable Sociomaterial Inquiry: A Computational Approach for Zooming In and Out of Sociomaterial Routines," MIS Quarterly (38:3), pp. 849-871.

Gheradi, S. 2012. How to Conduct a Practice-Based Study: Problems and Methods, Cheltenham, UK: Edward Elgar.

Gherardi, S., and Nicolini, D. 2002. "Learning in a Constellation of Interconnected Practices: Canon or Dissonance?," Journal of Management Studies (39:4), pp. 419-36. 
Giddens, A. 1984. The Constitution of Society: Outline of the Theory of Structuration, Oxford, UK: Polity Press.

Habermas, J. 1979. Communication and the Evolution of Society, Boston: Beacon Press.

Hanseth, O., and Monteiro, E. 1997. "Inscribing Behavior in Information Infrastructure Standards," Accounting, Management and Information Technology (7:4), pp. 183-211.

Haraway, D. J. 1991. “A Cyborg Manifesto: Science, Technology, and Socialist-Feminism in the Late Twentieth Century," Chapter 8 in Simians, Cyborgs and Women: The Reinvention of Nature, New York: Routledge, pp. 149-181.

Haraway, D. J. 1997. Modest_Witness@Second_Millenium. FemaleMan Meets OncoMouse, London: Routledge.

Harman, G. 2002. Tool-Being: Heidegger and the Metaphysics of Objects, Chicago: Open Court.

Hauptmann, S., and Steger, T. 2013. “"A Brave New (Digital) World'? Effects of In-House Social Media on HRM," Zeitschrift für Personalforschung (27:1), pp. 26-46.

Hedman, J., Srinivasan, N., Lindgren, R. 2013. "Digital Traces of Information Systems: Sociomateriality Made Researchable," in Proceedings of $34^{\text {th }}$ International Conference on Information Systems, Milan, Italy, December 15-18.

Henfridsson, O., and Yoo, Y. 2013. "The Liminality of Trajectory Shifts in Institutional Entrepreneurship," Organization Science (http://dx.doi.org/10.1287/orsc.2013.0883).

Huang, J., Newell, S., Huang, J., and Pan, S. 2014. "Site-Shifting as the Source of Ambidexterity: Empirical Insights from the Field of Ticketing," Journal of Strategic Information Systems (23:1), pp. 29-44.

Introna, L. D. 2011. "The Inframing of Code: Agency, Originality and the Plagiarist," Theory, Culture and Society (28:6), pp. 113-141.

Introna, L. D. 2013. "Otherness and the Letting-Be of Becoming: Or Ethics Beyond Bifurcation," in How Matter Matters: Objects, Artifacts, and Materiality in Organization Studies, P. R. Carlile, D. Nicolini, A. Langley, and H. Tsoukas (eds.), Oxford, UK: Oxford University Press, pp. 260-287.

Jarrahi, M. H., and Sawyer, S. 2013. "Social Technologies, Informal Knowledge Practices, and the Enterprise," Journal of Organizational Computing and Electronic Commerce (23:1-2), pp. 110-137.

Johnson, G., Langley, A., Melin, L., and Whittington, R. (eds.). 2007. Strategy as Practice: Research Directions and Resources, Cambridge, UK: Cambridge University Press.

Jones, M. 2013. "Understanding Sociomateriality," in How Matter Matters: Objects, Artifacts, and Materiality in Organization Studies, P. R. Carlile, D. Nicolini, A. Langley, and H. Tsoukas (eds.), Oxford, UK: Oxford University Press, pp. 197-226.

Jones, M. 2014. "A Matter of Life and Death: Exploring Conceptualizations of Sociomateriality in the Context of Critical Care," MIS Quarterly (38:3), pp. 895-925.

Kautz, K., and Jensen, T. B. 2013. "Sociomateriality at the Royal Court of IS: A Jester's Monologue," Information and Organization (23), pp. 15-27.

King, J., and Lyytinen, K. (eds.). 2006. Information Systems: The State of the Field, Chichester, UK: John Wiley \& Sons.
Latour, B. 2005. Reassembling the Social: An Introduction to Actor-Network-Theory, Oxford, UK: Oxford University Press.

Lave, J., and Wenger, E. 1991. Situated Learning: Legitimate Peripheral Participation, Cambridge, UK: Cambridge University Press.

Law, J. 2004. After Method: Mess in Social Science Research, London: Routledge.

Law, J. 2008a. "Actor-Network Theory and Material Semiotics," in The New Blackwell Companion to Social Theory ( $3^{\text {rd }}$ ed.), B. S. Turner (ed.), Oxford, UK: Blackwell Publishing, pp. 141-158.

Law. J. 2008b. "On STS and Sociology," The Sociological Review (56:4), pp. 623-649.

Leonardi, P. M. 2011. "When Flexible Routines Meet Flexible Technologies: Affordance, Constraint, and the Imbrication of Human and Material Agencies," MIS Quarterly (35:1), pp. 147-176.

Leonardi, P. M. 2012. "Materiality, Sociomateriality, and SocioTechnical Systems: What Do These Terms Mean? How Are They Different?," in Materiality and Organizing: Social Interaction in a Technological World, P. M. Leonardi, B. A. Nardi, and J. Kallinikos (eds.), Oxford, UK: Oxford University Press, pp. 25-48.

Leonardi, P. M. 2013. "Theoretical Foundations for the Study of Sociomateriality," Information and Organization (23), pp. 59-76.

Leonardi, P. M., and Barley, S. R. 2008. "Materiality and Change: Challenges to Building Better Theory about Technology and Organizing," Information and Organization (18), pp. 159-176.

Leonardi, P. M., and Barley, S. R. 2010. "What Is Under Construction Here? Social Action, Materiality, and Power in Constructivist Studies of Technology and Organizing," The Academy of Management Annals (4:1), pp. 1-51.

Leonardi, P. M., Nardi, B., and Kallinikos, J. (eds.). 2012. Materiality and Organizing: Social Interaction in a Technological World, Oxford, UK: Oxford University Press.

Liang, H., Xue, Y., and Wu, L. 2013. "Ensuring Employees' IT Compliance: Carrot or Stick?," Information Systems Research (24:2), pp. 279-294.

Locke, K. 2011. "Field Research Practice in Management and Organization Studies: Reclaiming its Tradition of Discovery," The Academy of Management Annals (5:1), pp. 613-652.

Markus, M. L., and Silver, M. S. 2008. "A Foundation for the Study of IT Effects: A New Look at DeSanctis and Poole's Concept of Structural Features and Spirit," Journal of the Association for Information Systems (9:10/11), pp. 609-632.

Mayer-Schönberger, V., and Cukier, K., 2013. Big Data: A Revolution that Will Transform how We Live, Work, and Think, New York: Houghton Mifflin Harcourt.

Mazmanian, M., Cohn, M., and Dourish, P. 2014. "Dynamic Reconfiguration in Planetary Exploration: A Sociomaterial Ethnography," MIS Quarterly (38:3), pp. 831-848.

Mazmanian, M., Orlikowski, W. J., and Yates, J. 2013. "The Autonomy Paradox: The Implications of Mobile Email Devices for Knowledge Professionals," Organization Science, Articles in Advance (DOI:10.1287/orsc.1120.0806).

Miles, M. B., and Huberman, A. M. 1994. Qualitative Data Analysis: An Expanded Sourcebook ( $2^{\text {nd }}$ ed.), Thousand Oaks, CA: Sage Publications. 
Mingers, J. 2001. "Combining IS Research Methods: Towards a Pluralist Methodology," Information Systems Research (12), pp. 240-259.

Mingers, J., and Willcocks, L. (eds.). 2004. Social Theory and Philosophy for Information Systems, Chichester, UK: John Wiley \& Sons.

Mingers, J., Mutch, A., and Willcocks, L. 2013. "Critical Realism in Information Systems Research,” MIS Quarterly (37:3), pp. 795-802.

Mitev, N., and Howcroft, D. 2011. "Post-Structuralism, Social Shaping of Technology, and Actor-Network Theory: What Can They Bring to IS Research?," in The Oxford Handbook of Management Information Systems, R. D. Galliers, and W. L. Currie (eds.), Oxford, UK: Oxford University Press, pp. 292-322.

Mol, A. 1999. “Ontological Politics. A Word and Some Questions," in Actor Network Theory and After, J. Law and J. Hassard (eds.), Oxford, UK: Blackwell, pp. 74-89.

Mol, A. 2002. The Body Multiple: Ontology in Medical Practice, Durham, NC: Duke University Press.

Mumford, E. 1983. Designing Human Systems: For New Technology, Manchester, UK: Manchester Business School.

Mumford, E. 2003. Redesigning Human Systems, Hershey, PA: Idea Publishing Group.

Mumford, E. 2006. "The Story of Socio-Technical Design: Reflections on its Successes, Failures and Potential," Information Systems Journal (16), pp. 317-342.

Mutch, A. 2013. "Sociomateriality_Taking the Wrong Turning?," Information and Organization (23), pp. 28-40.

Nicolini, D. 2009. "Zooming In and Out: Studying Practices by Switching Lenses and Trailing Connections," Organization Studies (30:12), pp. 1391-1418

Nicolini, D. 2013. Practice Theory, Work, and Organization: An Introduction, New York: Oxford University Press.

Oborn, E., Barrett, M., and Dawson, S. 2013. "Distributed Leadership in Policy Formulation: A Sociomaterial Perspective," Organization Studies (34:2), pp. 253-276.

Orlikowski, W. J. 2002. "Knowing in Practice: Enacting a Collective Capability in Distributed Organizing," Organization Science (13:3), pp. 249-273.

Orlikowski, W. J. 2005. "Material Works: Exploring the Situated Entanglement of Technological Performativity and Human Agency," Scandinavian Journal of Information Systems (17:1), pp. 183-186.

Orlikowski, W. J. 2006. "Material Knowing: The Scaffolding of Human Knowledgeability," European Journal of Information Systems (15:5), pp. 460-466.

Orlikowski, W. J. 2007. "Sociomaterial Practices: Exploring Technology at Work," Organization Studies (28:9), pp. 1435-1448.

Orlikowski, W. J. 2010. "The Sociomateriality of Organizational Life: Considering Technology in Management Research," Cambridge Journal of Economics (34:1), pp. 125-141.

Orlikowski, W. J., and Iacono, C. S. 2001. "Research Commentary: Desperately Seeking the 'IT' in IT Research-A Call to Theorizing the IT Artifact," Information Systems Research (12:2), pp. 121-134.
Orlikowski, W. J., and Scott, S. V. 2008. "Sociomateriality: Challenging the Separation of Technology, Work and Organization," The Academy of Management Annals (2:1), pp. 433-474.

Orlikowski, W. J., and Scott, S. V. 2013. "Knowledge Eclipse: Producing Sociomaterial Reconfigurations in the Hospitality Sector," in How Matter Matters: Objects, Artifacts, and Materiality in Organization Studies, P. R. Carlile, D. Nicolini, A. Langley, and H. Tsoukas (eds.), Oxford, UK: Oxford University Press, pp. 119-141.

Østerlie, T., Almklov, P. G., and Hepsø, V. 2012. "Dual Materiality and Knowing in Petroleum Production," Information and Organization (22:2), pp. 85-105.

Panourgias, N. S., Nandhakumar, J., and Scarbrough, H. 2013. "Entanglements of Creative Agency and Digital Technology: A Sociomaterial Study of Computer Game Development," Technological Forecasting and Social Change (83), pp. 111-126.

Pentland, B., Haerem, T., and Hillison, D. 2011. "The (N)EverChanging World: Stability and Change in Organizational Routines," Organization Science (22:6), pp. 1369-1383.

Peppard, J., Galliers, R. D., and Thorogood, A. 2014. "Information Systems Strategy as Practice: Micro Strategy and Strategizing for IS," Journal of Strategic Information Systems (23:1), pp. $1-10$.

Philips, N., and Oswick, C. 2012. "Organizational Discourse: Domains, Debates, and Directions," The Academy of Management Annals (6:1), pp. 435-481.

Pickering, A. 1993. "The Mangle of Practice: Agency and Emergence in the Sociology of Science," American Journal of Sociology (99:3), pp 559-589.

Pickering, A. 1995. The Mangle of Practice: Time, Agency, and Science, Chicago: The University of Chicago Press.

Pollock, N., and D'Adderio, L. 2012. "Give Me a Two-by-Two Matrix and I Will Create the Market: Rankings, Graphic Visualizations and Sociomateriality. Accounting, Organizations and Society (37:8), pp. 565-586.

Porter, A. J. 2013. "Emergent Organization and Responsive Technologies in Crisis: Creating Connections or Enabling Divides?," Management Communication Quarterly (26:1), pp. 6-33.

Pritchard, K., and Symon, G. 2013. "Picture Perfect? Exploring the Use of Smartphone Photography in a Distributed Work Practice," Management Learning (DOI 10.1177/1350507613486424).

Riemer, K., and Johnston, R. 2012. "Place Making: A Phenomenological Theory of Technology Appropriation," in Proceedings of the $33^{\text {rd }}$ International Conference on Information Systems, Orlando, Florida, December 16-19.

Rezkwitz, A. 2002. "Toward a Theory of Social Practice," European Journal of Social Theory (5:2), pp. 243-263.

Robey, D., Anderson, C., and Raymond, B. 2013. "Information Technology, Materiality, and Organizational Change: A Professional Odyssey," Journal of Association for Information Systems (14:7), pp. 379-398.

Rouse, J. 2007. "Social Practice and Normativity," Philosophy of the Social Sciences (37:1), pp. 46-56.

Sarker, S., Sarker, S., and Sidorova, A. 2006. "Understanding Business Process Change Failure: An Actor-Network Perspective," Journal of Management Information System (23:1), pp. 51-86. 
Sassen, S. 2006. Territory, Authority, Rights: From Medieval to Global Assemblages, Princeton, NJ: Princeton University Press.

Schatzki, T. R. 1996. Social Practices: A Wittgensteinian Approach to Human Activity and the Social, Cambridge, UK: Cambridge University Press.

Schatzki, T. R. 2002. The Site of the Social: A Philosophical Exploration of the Constitution of Social Life and Change, University Park, PA: Pennsylvania State University Press.

Schatzki, T. R. 2005. "The Site of Organizations," Organization Studies (26), pp. 465-484.

Schultze, U., and Mason, R. O. 2012. "Studying Cyborgs: Reexamining Internet Studies as Human Subjects Research," Journal of Information Technology (27:4), pp. 1-12.

Scott, S. V., and Orlikowski W. J. 2012. "Great Expectations: The Materiality of Commensurability in Social Media," in Materiality and Organizing: Social Interaction in a Technological World, $\mathrm{P}$. M. Leonardi, B. A. Nardi, and J. Kallinikos (eds.), Oxford, UK: Oxford University Press, pp. 113-133.

Scott, S. V., and Orlikowski, W. J. 2013. "Sociomateriality: Taking the Wrong Turning? A Response to Mutch," Information and Organization (23), pp. 77-80.

Scott, S. V., and Orlikowski, W. J. 2014. "Entanglements in Practice: Performing Anonymity Through Social Media," MIS Quarterly (38:3), pp. 863-893.

Shotter, J. 2013. "Reflections on Sociomateriality and Dialogicality in Organization Studies: From 'Inter-' to 'Intra-Thinking' ... in Performing Practices," in How Matter Matters: Objects, Artifacts, and Materiality in Organization Studies, P. R. Carlile, D. Nicolini, A. Langley, and H. Tsoukas (eds.), Oxford, UK: Oxford University Press, pp. 32-57.

Singer, E. A. 1959. Experience and Reflection, Philadelphia, PA: University of Pennsylvania Press.

Slade, B. 2013. "Professional Learning in Rural Practice: A Sociomaterial Analysis," Journal of Workplace Learning (25:2), pp. 114-124.

Slife, B. D. 2004. "Taking Practice Seriously: Toward a Relational Ontology," Journal of Theoretical and Philosophical Psychology (24:2), pp. 157-178.

Star, S. L. 2010. "Ceci n'est Pas un Objet-frontière: Réflexions sur l'Origine d'en Concept" [This Is Not a Boundary Object: Reflections on the Origin of a Concept], Revue d'Antropologie des Connaisances (4:1), pp. 18-35.

Stein, M., Galliers, R. D., and Markus, M. L. 2013. "Towards an Understanding of Identity and Technology in the Workplace," Journal of Information Technology (28:3), pp. 167-182.

Suchman, L. A. 2007. Human-Machine Reconfigurations: Plans and Situated Actions ( $2^{\text {nd }}$ ed.), Cambridge, UK: Cambridge University Press.
Trist, E. 1981. "The Evolution of Socio-Technical Systems: A Conceptual Framework and an Action Research Program," Occasional Paper No.2, Ontario Quality of Working Life Centre (http://www.sociotech.net/wiki/images/9/94/Evolution_of_ socio_technical_systems.pdf).

Trist, E., and Bamforth, W. 1951. "Some Social and Psychological Consequences of the Long Wall Method of Coal-Getting," Human Relations (4), pp. 3-38.

Venters, W., Oborn, E., and Barrett, M. 2014. "A Trichordal Temporal Approach to Digital Coordination: The Sociomaterial Mangling of the CERN Grid," MIS Quarterly (38:3), pp. 927-949.

Vidgen, R., and McMaster, T. 1996. "Black Boxes: Non-Human Stakeholders and the Translation of IT Through Mediation," in Information Technology and Change in Organizational Work, W. J. Orlikowski, G. Walsham, M. R. Jones, and J. I. DeGross (eds.), London: Chapman \& Hall, pp. 250-271.

Wagner, E. L., Newell, S. M., and Moll, J. 2011. “Accounting Logics, Reconfiguration of ERP Systems \& the Emergence of New Accounting Practices: A Sociomaterial Perspective," Management Accounting Research (22), pp. 181-197.

Wagner, E. L., Newell, S. M., and Piccoli, G. 2010. "Understanding Project Survival in an ES Environment: A Sociomaterial Practice Perspective," Journal of the Association for Information Systems (11:5), pp. 276-298.

Walsham, G. 1993. Interpreting Information Systems in Organizations, New York: John Wiley and Sons.

Whalen, J., Whalen, M., and Henderson, K. 2002. "Improvisational Choreography in Teleservice Work," The British Journal of Sociology (53:2), pp. 239-258.

Whittington, R. 2006. "Completing the Practice Turn in Strategy Research,” Organization Studies (27:5), pp. 613-634.

Whittington, R. 2014. "Information Systems Strategy and Strategyas-Practice: A Joint Agenda," Journal of Strategic Information Systems (23:1), pp. 87-91.

Woolgar, S. 2002. "After Word: On Some Dynamics of Duality Interrogation," Theory, Culture and Society (19:5/6), pp. 261-270.

Yoo, Y. 2010. "Computing in Everyday Life: A Call for Research on Experiential Computing," MIS Quarterly (34:2), pp. 213-231.

Yoo, Y. 2013. "The Tables Have Turned: How Can the IS Field Contribute to Technology and Innovation Management Research?," Journal of the Association for Information Systems, Special Issue on the Frontiers of Information (14:5), pp. 227-36. 